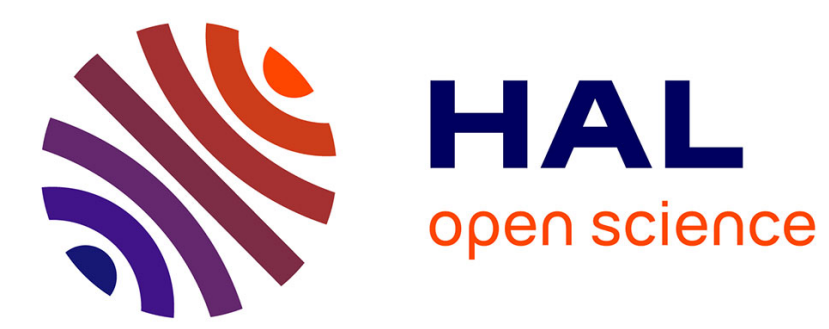

\title{
Improving skills for more and better jobs?
}

Andrea Bassanini

\section{To cite this version:}

Andrea Bassanini. Improving skills for more and better jobs?. European Economy: Special Reports, 2004, 3, pp.103-137. halshs-00169612

\section{HAL Id: halshs-00169612 https://shs.hal.science/halshs-00169612}

Submitted on 6 Nov 2007

HAL is a multi-disciplinary open access archive for the deposit and dissemination of scientific research documents, whether they are published or not. The documents may come from teaching and research institutions in France or abroad, or from public or private research centers.
L'archive ouverte pluridisciplinaire HAL, est destinée au dépôt et à la diffusion de documents scientifiques de niveau recherche, publiés ou non, émanant des établissements d'enseignement et de recherche français ou étrangers, des laboratoires publics ou privés. 


\section{Chapter 8}

\section{Improving skills for more and better jobs? The quest for efficient policies to promote adult education and training $\left({ }^{1}\right)$}

Andrea Bassanini (OECD) (2)

( $\left.{ }^{1}\right)$ This paper partially draws on the work done by the author for the 2003 and 2004 editions of the OECD Employment outlook. However, the views expressed here are those of the author and cannot be attributed to the OECD or its member countries. I thank Wooseok Ok, Peter Tergeist and Greg Wurzburg for their help in collecting policy examples and useful discussions about policy issues. Useful comments from Ken Swinnerton, Matthew James, Raymond Torres, Martine Durand, John Martin, David Young and Thomas Zwick on different parts of this paper are also acknowledged. Sebastien Martin provided excellent research assistance. All errors are mine.

(2) Economist in the OECD Directorate for Employment, Labour and Social Affairs, 2 rue André Pascal, F-75775 Paris Cedex 16; e-mail: andrea.bassanini@ oecd.org. 


\section{Introduction}

Viewed from the point of view of employment policy, the rationale behind stressing the importance of lifelong upgrading of skills and competences is threefold. First, technological and structural changes render jobs and skills obsolete at such a rate that the slow renewal of the labour force through the entry of young qualified workers might not suffice to satisfy the demand for new qualifications, thereby increasing the risk of skill shortages that, in a global economy, may depress employment (OECD, 1994, Chapter 7). Second, people with low qualifications face higher unemployment prospects or, in countries where they can price themselves into jobs, a higher risk of being persistently in low pay and often in poverty. Policies for initial education and adult training can, therefore, be seen as complementary to making-work-pay policies and job-search assistance as regards to "minimising the number of people who do not attain and maintain the skills required to command earnings that bring them above the poverty threshold' (OECD, 1999, p. 12). Third, as skills become outdated more quickly than workers retire from the labour force, there is a strong risk of older workers losing their current jobs, while lacking the competencies to move into new jobs. Indeed, since increasing labour market participation of older workers has become a policy priority of many industrialised countries, 'promoting access to training for all regardless of age and developing lifelong learning strategies, in particular workplace training for older workers' (European Commission, 2004, p. 46) has gained paramount attention.

It can be argued, however, that there is still little empirical evidence that can support the policy-maker's emphasis on adult learning. The evidence on the impact of government funded training programmes for the unemployed is mixed $\left({ }^{1}\right)$. The evidence on the impact of training for employed workers is essentially limited

(1) See for example Heckman et al. (1999), Martin and Grubb (2001), Layard (2003), and Betcherman et al. (2004). to its average effect on wages and productivity $\left({ }^{2}\right)$, while only few studies look at the relationship between employee training and employment security, and their results are somewhat inconclusive due to selection bias $\left(^{3}\right)$. Furthermore, the fact that, while workers' participation in education and training is relatively high in certain countries, the number of hours of training received by each participant is much smaller than those received by full-time students enrolled in front-end education might cast doubts on how much a marginal improvement in training provision can affect labour market performance, in general, and, more specifically, individual and aggregate employment perspectives. Finally, deadweight and efficiency are seldom considered in the policy discourse.

This paper is a very partial attempt to contribute to bridge this gap. First, I use data from the European Community household panel to try to assess the effects of adult education and training on individual labour market performance. My findings seem to confirm that training makes a difference. Although I find that employee training has a clear impact on wage growth only in the case of young or highly educated employees, it appears to have a stronger impact on employment security - at least insofar as it is perceived by the workers - in the case of both older and low-educated workers. To reconcile this apparent contradiction, we need to take into account that training wage premia are estimated on a censored sample including only employed workers. Due to the existence of downward wage rigidity, one can expect that those workers who are unable to maintain their productivity (due, for instance, to skill obsolescence) are more frequently laid off — rather than experiencing a fall in wages and be retained in employment - and thereby excluded from our sample. In particular, it can be conjectured that, in the case of older

(2) Two exceptions to be noted are Leuven and Oosterbeek (2004) and Arulampalam et al. (2004a)

$\left.{ }^{3}\right)$ See Bishop (1997) and Ok and Tergeist (2003) amongst others. 
workers, training enables employers to match individual productivity with constant individual wages and therefore retain the worker. Conversely, workers not receiving training are more likely to enter non-employment because their productivity has fallen below their wage. This argument can be generalised to all low-productivity workers and suggests that, for those people who find it more difficult to price themselves into jobs, training allows attaining and maintaining the competences required to match productivity and wages, thereby sustaining their employment prospects. Once foregone income due to unemployment spells is taken into account, it turns out that training positively affects earnings at any age and level of educational attainment.

Second, by looking at the recent experience of many industrialised countries, I argue that, to compensate for the effect of possible market failures, which might justify training policy in spite of high ex post private return, co-financing arrangements - under which governments, employers and/or employees jointly finance training — can better leverage the required resources to upgrade the competences of those in employment. Co-financing schemes, if carefully designed, can minimise deadweight losses, although specific programmes for the unemployed or the inactive might require full government funding.

The paper is organised as follows: Section 2 sets forth and estimates a simple empirical model for evaluating the effect of training on individual wages and subjective perceptions of employment security. Section 3 discusses the main sources of market failures affecting training outcomes and the empirical evidence on their relevance. Section 4 explains the logic underlying the co-financing approach to training policy and reviews recent policy innovation adopted in this area by several OECD countries. Few concluding remarks are contained in the final section. 


\section{Do workers benefit from training?}

\subsection{Empirical framework}

The general empirical model used in this paper can be considered an extension of that proposed by Loewenstein and Spletzer (1998). Denote with $V_{i j t}$ the value for the worker $i$ of a job match with the firm $j$ at time $t$. In the simplest case this value can be seen as the stream of expected revenues that the worker $i$ can obtain from being employed in firm $j$ at time $t$. In a narrow sense we can think of this value as the current wage. However, more generally, this value may include the worker's valuation of his/her employment security and/or expected future wages. Our objective is to estimate the effect on $V_{i j t}$ of the stock of previously taken training courses.

Whatever the precise definition of $V_{i j t}$, which will depend on the specific empirical application, let us assume that it can be written as

$$
V_{i j t}=\beta \mathrm{X}_{i t}+\gamma T_{i j t}^{c}+\delta T_{i j t}^{p}+y_{t}+\mu_{i}+v_{i j t}+\varepsilon_{i t}
$$

where $\mathrm{X}_{i t}$ is a vector of time-varying individual characteristics, $T_{i j t}^{c}$ is the stock of training taken while working for the current employer, $T_{i j t}^{p}$ the stock of training taken while working for previous employers, while $y_{t}$, $\mu_{i}, v_{i j t}$ are year (or country per year) effects, individual fixed effects and job-match-specific effects (with $v_{i j t}$ taking value $v_{i j}$ if the worker $i$ has a job with firm $j$ at time $t$ and 0 otherwise), respectively, and $\varepsilon_{i t}$ is a standard random disturbance.

Assuming that [1] is valid, it is equivalent to ruling out time-variant heterogeneity, which is not due to observable characteristics (such as the training stock), the jobmatch or a serially uncorrelated random disturbance.
The inclusion of an individual fixed effect in the empirical specification allows identifying the coefficient of all stock variables (such as training) for which only changes within the sample period are observable (depreciation is ruled out for convenience). However, if in addition match-specific effects are included in the empirical specification, the impact of $T_{i j t}^{p}$, being invariant within each specific job-match, cannot be identified.

Loewenstein and Spletzer (1998) show that if $\gamma<\delta$ then estimating [1] by omitting match-specific effects (but including individual fixed effects) would yield an estimate $\hat{\delta}<\delta$, provided that dummies for the number of job changes are included in the specification. Equivalently, the same result can be obtained by estimating model [1] in first differences using OLS, omitting match-specific effects and including a dummy for job change. Conversely, to obtain unbiased estimates of $\gamma$, job-match-specific means can be subtracted from the stock of training taken with the current employer. Indeed, corr $\left(\left(T_{i j t}^{c}-\bar{T}_{i j}^{c}\right), v_{i j}\right)=0$ by construction $\left(\bar{T}_{i j}^{c}\right.$ denoting the job-match-specific mean of $\bar{T}_{i j t}^{c}$ ).

\subsection{The data}

I use longitudinal data from the 2003 release of the European Community household panel (ECHP). This survey provides a wealth of information on individual income and socioeconomic characteristics for $15 \mathrm{EU}$ countries and aims to be representative, both in crosssections and longitudinally. Due to the common questionnaire, the information contained in the ECHP is, in principle, comparable across countries, which is its main strength. Moreover, releases of the ECHP contain additional longitudinal data from other sources for certain countries - such as the German socio- 
economic panel (SOEP) and the British household panel survey (BHPS), whose questions are made comparable with those of the ECHP questionnaire.

The main question on vocational training in the ECHP is as follows 'Have you at any time since January (year before the survey year) been in any vocational education or training, including part-time and short courses?'. From this question, a dichotomous variable 'participation in vocational training', which takes the value 1 if the individual responded 'yes' and 0 if he/ she responded 'no', is constructed. Conditional on a positive answer, the individual is asked to report additional information on the last course only (including duration but, in the case of education courses, not including whether the course was paid for or provided by the employer). The distinction between formal education and vocational training is based on the categories used by national labour force surveys.

In the year of the interview, the stock of vocational training and formal education is increased by 1 if the individual reported to have participated in one of them in the period covered by that interview. Each training stock is further decomposed in two aggregates: training taken with the current employer and training taken with previous employers. Due to the scattered nature of the information on course duration (with many missing values for many countries), start and end dates are not used for the analysis of this paper. This has two consequences. First, training reported in one interview is attributed to belong to the period between that interview and the previous one, although it might have been taken before the latter. This is equivalent to increasing the risk of false reporting, which, as shown by Frazis and Loewenstein (1999), is likely to bias returns towards zero. Second, training reported in one interview is considered to have been taken with the current employer at the time of the interview. If, at a given interview, the individual says he/she has separated from the employer he/she was working for at the time of the previous interview, the training reported in previous interviews as training with the current employer is added to the stock of training taken with previous employers and the stock of training with the current employer is re-set to either 0 or 1 (depending on whether any training is reported in the current interview). Additional information on the data used is reported in the appendix.

\subsection{Empirical results}

\section{Training wage premia}

There are various ways to compute a training wage premium $\left(^{1}\right)$. The simplest method, when longitudinal data are available, is to compare wage growth rates $\left(^{2}\right)$ between two interviews for workers receiving/not receiving training between the same two interviews. This procedure already controls for time-invariant heterogeneity without resorting to sophisticated regression techniques. Chart 1 shows simple average measures of the wage premium computed along these lines, by pooling together all countries and years for which the information is available.

Cross-country differences in the bivariate trainingwage growth relationship are large (ranging from wages $0.1 \%$ greater after participation in some education and training in France and the United Kingdom to wages $4.5 \%$ greater in Portugal). Raw training premia are lower in many countries when computed with respect to vocational training only (excluding education), but remain positive in all but three countries (Belgium, Ireland and the United Kingdom). On average, the bivariate training-wage growth relationship seems to decline with age and educational attainment, although this pattern is much less evident in the case of vocational training only. Finally, contrary to what is suggested by simulation exercises based on crosssection information only (see OECD, 2003b), once individual heterogeneity is controlled for, training wage premia seem to be lower for women than for men, possibly due to heterogeneity in the quality of training courses and/or occupational gender segregation (see OECD, 2002).

As discussed above, workers employed by high-performing establishments (for example those belonging to more innovative firms) might receive more training and experience faster wage growth. Furthermore, for policy purposes, it is important to know whether workers' ben-

(1) The economic literature is crowded with empirical results on the issue. See Bishop (1997), Leuven (2003) and Ok and Tergeist (2003) for recent surveys. Among the papers not covered by these review articles, see also Parent (1999) and Hill (2001), Kurosawa (2001), Hui and Smith (2002), Schøne (2002), Gerfin (2003), Kuckulenz and Zwick (2003) and Arulampalam et al. (2004a) for the USA, Japan, Canada, Norway, Switzerland, Germany, and European Union countries, respectively. For Canada, see also OECD (2003b), although the estimates contained in this study refer only to individuals who actually upgraded their formal education diploma.

$\left.{ }^{2}\right)$ The wage concept used in this paper is gross hourly wage in the main job, including paid overtime and overtime hours. 


\section{Chart 1: Wage growth difference between trained and untrained employees, by country and by labour market group}

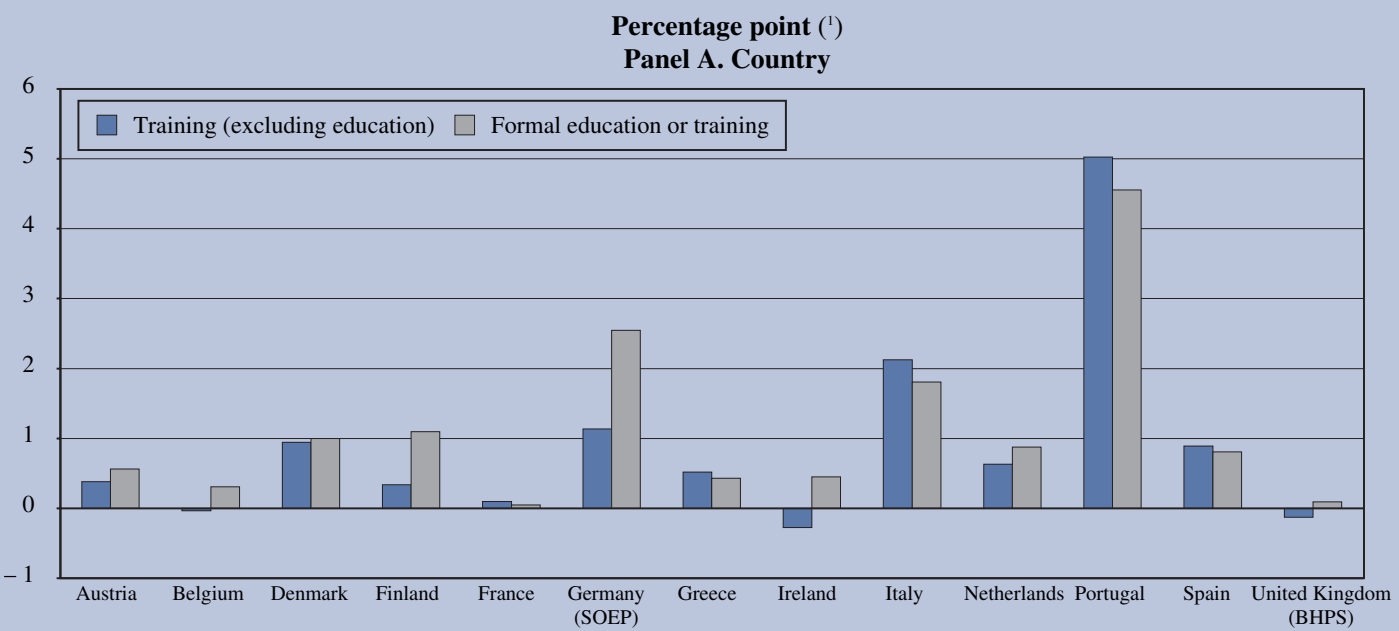

Panel B. Labour market group $\left(^{2}\right)$

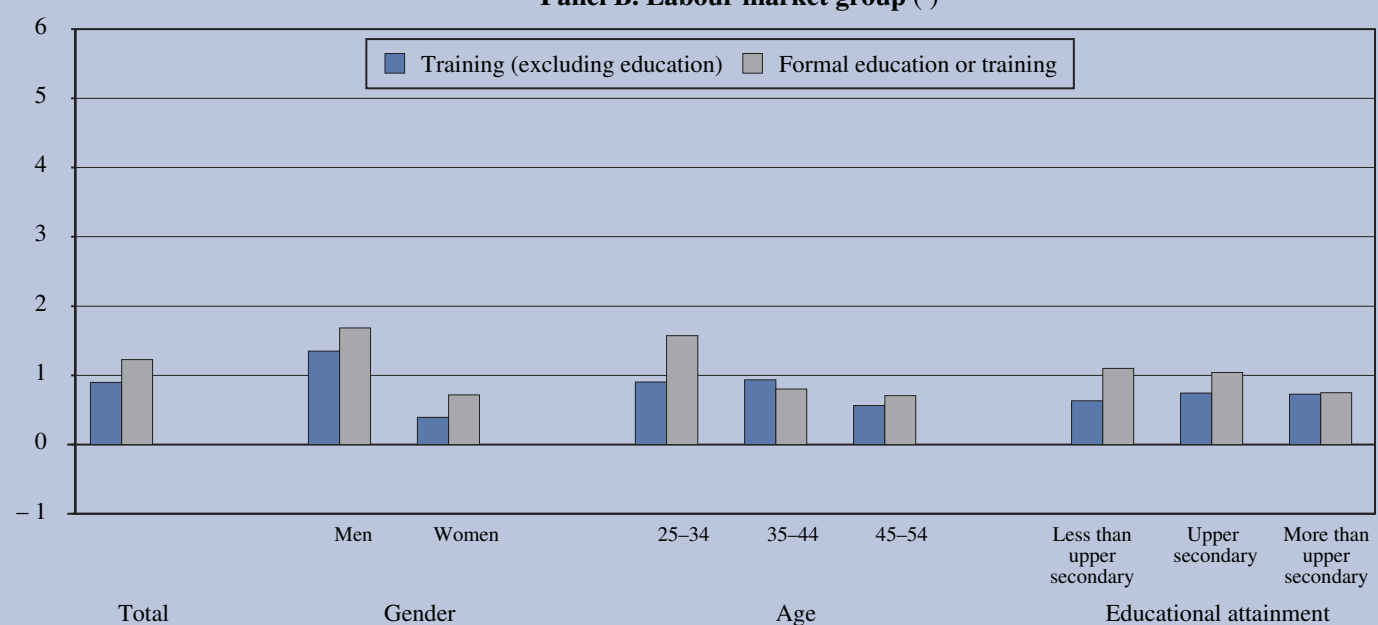

$\left({ }^{1}\right)$ Percentage-point difference in average annual wage growth rates between employees receiving training between two interviews and those not receiving it. Figures are adjusted to take into account that the time spell between two interviews can be different from one year. Data refer to wage and salary workers aged 25-54 years and working more than 15 hours per week.

${ }^{2}$ ) Estimates based on the countries shown in Panel A

Source: Own calculations based on the European Community household panel, waves 1 to 7 (1994-2000).

efits from training are transferable across jobs and employers. This is particularly important in the context of policy reforms geared towards making the labour market more flexible and the resource allocation more rapid and smoother. Chart 2 decomposes the raw training premia presented above into the premium to training 
taken with the current employer - estimated by correcting for match-specific heterogeneity $\left({ }^{1}\right)$ - and the premium to training taken with previous employers, while Table 1 presents fully-fledged multivariate estimates of the training premia, after correcting also for changes in observable individual and firm characteristics $\left(^{2}\right)$.

In all countries for which data are available, continuous education and training taken with previous employers have, on average, a positive impact on wages, although this impact is not always significant in Belgium, Italy and Portugal. Using the most reliable model (Table 1), participating in formal education and training in one year is estimated to increase earnings by up to $5.8 \%$ (in Austria). Workers usually reap a lower (and sometimes insignificant) premium while staying with the same employer. These results are also broadly confirmed when wage premia to training and education are estimated separately, although estimates are less precise - and somewhat lower in the case of vocational training $\left(^{(3)}\right.$. The fact that the wage premium to training taken with previous employers is smaller in the case of vocational training than in the case of formal education is not surprising because competences acquired through formal education are more easily signalled and recognised. Accreditation and recognition of competences acquired through short vocational training spells and informal training is indeed a crucial issue (and policy problem) for the transferability of training (see below).

(1) Match-specific effects on wage premia to training taken with current employers are eliminated by subtracting job-match-specific means from the stock of training taken with the current employer. A sensitivity analysis (not presented here) was undertaken by estimating wage equations with job-match fixed effects, and revealed that the two procedures give extremely close results as regards to training taken with the current employer. As far as training taken with previous employers is concerned, there is less need to correct for the effect of match-specific events because, as shown by Loewenstein and Spletzer (1998), to the extent that returns to training taken with previous employers are no smaller than those to training taken with the current employers, the former are underestimated.

${ }^{2}$ ) Controlling for changes in observable characteristics allows partial correction for other sources of time-variant heterogeneity. However, it is cautious to compare this model with simpler ones without covariates (such as the model behind Chart 12) because, if returns to training are heterogeneous and selection bias is not fully eliminated by including match-specific effects, mis-specification of the linear regression model may result in large estimation biases (see, for example, Lalonde, 1986, Heckman et al., 1999, and Smith and Todd, 2004). A more sophisticated approach to correct for time-variant heterogeneity and selection bias would be to use instrumental variables. However, the difficulty to find appropriate instruments makes this approach infrequent in the literature, the only example known to us being an unpublished paper by Blundell et al. (1999).

${ }^{3}$ ) Still, in both specifications, they are significant at the $10 \%$ level in almost all countries for which separate premia could be estimated (to limit the risk of unreliability, country-specific estimates are not computed when there are less than 100 individuals who received some training before a job change within the sample window and/or when these individuals represent less than $2 \%$ of the sample of individuals)
Overall, these findings are consistent with previous studies that typically find the training premium increases in the aftermath of a job change (see Loewenstein and Spletzer, 1998, 1999 and Parent, 1999, for the USA; Fougère et al., 2001, for France; Blundell et al., 1999, and Booth and Bryan, 2002, for the United Kingdom; and Gerfin, 2003, for Switzerland). These papers tend to interpret the fact that the training wage premium increases in the aftermath of job change as evidence of employers' market power (I will get back to this point in Section 3). However, there are at least two other possible explanations. First, the training firm does not always have a high-pay position to offer to the trained worker. In this case - if competences acquired through training are transferable - trained workers may have better options outside the firm. Second, workers might accept to be paid less than their marginal product in the current job if they are sensitive to reciprocity. In particular, workers might interpret the firm's investment in general training as a kind action which deserves reward. Anticipating this, the firm might invest more in general training than it would have done in the presence of purely opportunistic behaviour. Consistent with the latter explanation, Leuven et al. (2004) use Dutch data to show that the probability of receiving employer-sponsored training for workers that are greatly sensitive to reciprocity is $15 \%$ higher than for workers who are not ready to reciprocate.

Looking at the pooled country sample and breaking this sample by labour market groups is instructive in many respects. First, the wage premium to participating in training in one previous year while already working for the current employer has an impact which is relatively homogeneous across groups (about $1 \%$ ), with in most cases a lower premium to formal education than to vocational training. Although this finding is partially due to too few education spells in the sample, it might be also ascribed to the fact that adults enrol in general education to qualify for different jobs rather than to improve the competencies they can use within the same job or occupation. Second, the impact of vocational training on wages seem to be transferable across jobs only in the case of relatively young and/or high educated workers, while the pattern is less clear for formal education, again partially due to the lack of precision of the estimates because of the limited number of education spells in the sample.

Should one conclude that education and training does not lead to a durable economic return for other categories, and particularly for those who have already lower 


\section{Chart 2: $\quad$ Training premia, by country and training history $\left({ }^{(}\right)$}
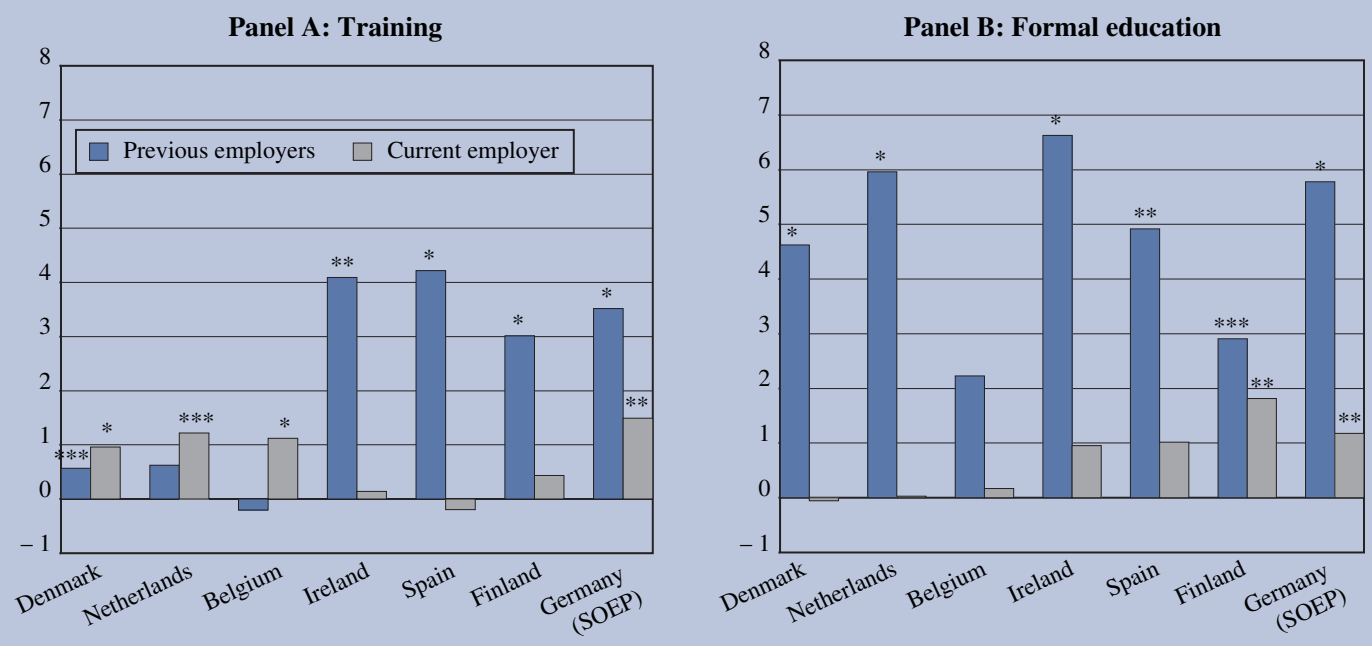

Panel C: Formal education or training

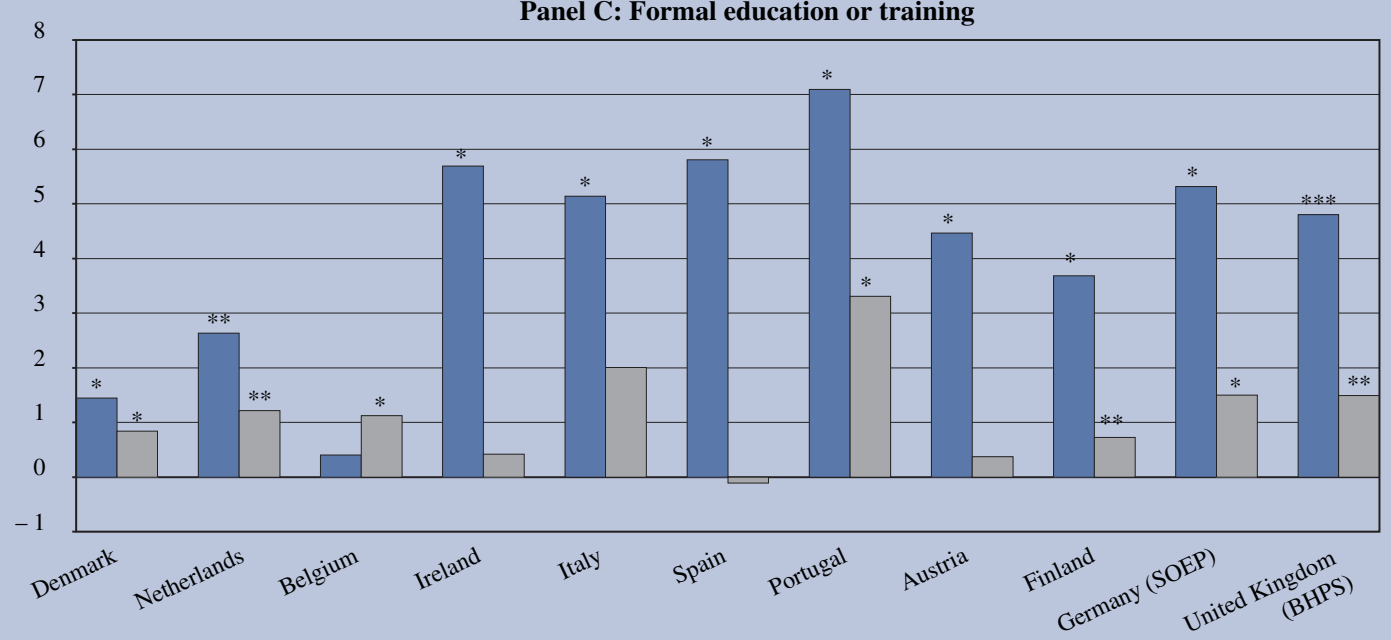

$*, * *, * * *$ Statistically significant at $1 \%$ level, $5 \%$ level and $10 \%$ level, respectively.

( ${ }^{1}$ Estimates of the wage premium of participating in training in one additional year obtained from the estimation of a simple wage equation with additional controls only for individual fixed effects, the number of previous jobs and interaction terms between country dummies, year dummies and date of interview. Training taken with the current employer has been demeaned by subtracting job-match-specific means. Wage premia to training and formal education are estimated through a specification that simultaneously includes both variables.

Source: Own calculations based on the European Community household panel, waves 1 to 7 (1994-2000).

earnings, greater employment insecurity as well as more imperfect access to training opportunities? As said above, this conclusion would be unwarranted. In fact, these returns are biased by the fact that the sample is censored: they are computed only for workers that are employed, excluding persons that are expelled from employment. To put it another way, these estimates do not take into account the impact of training on employment prospects and on containing the loss of income associated with unemployment spells. 


\section{Table 1}

Panel data estimates of training premia, by country and labour market group

\begin{tabular}{|c|c|c|c|c|c|c|}
\hline \multirow[b]{5}{*}{ Denmark } & \multicolumn{6}{|c|}{ Percentage $\left({ }^{1}\right)$} \\
\hline & \multicolumn{2}{|c|}{$\begin{array}{l}\text { Training } \\
\text { taken with }\end{array}$} & \multicolumn{2}{|c|}{$\begin{array}{l}\text { Formal education } \\
\text { taken with }\end{array}$} & \multicolumn{2}{|c|}{$\begin{array}{l}\text { Formal education or } \\
\text { training taken with }\end{array}$} \\
\hline & $\begin{array}{l}\text { Previous } \\
\text { employers }\end{array}$ & $\begin{array}{l}\text { Current } \\
\text { employer }\end{array}$ & $\begin{array}{l}\text { Previous } \\
\text { employers }\end{array}$ & $\begin{array}{l}\text { Current } \\
\text { employer }\end{array}$ & $\begin{array}{l}\text { Previous } \\
\text { employers }\end{array}$ & $\begin{array}{l}\text { Current } \\
\text { employer }\end{array}$ \\
\hline & \multicolumn{6}{|c|}{ Panel A. Country } \\
\hline & $1.60 *$ & $0.87 *$ & $4.39 *$ & 0.17 & $2.26 *$ & 0.78 \\
\hline Netherlands & 0.48 & 0.44 & $6.12^{*}$ & 0.23 & $2.78 * *$ & 0.58 \\
\hline Belgium & $2.30 * * *$ & $1.84^{*}$ & -1.20 & -1.84 & $2.12 * * *$ & $1.57 *$ \\
\hline Ireland & $3.31 * * *$ & 0.21 & $6.15^{*}$ & 0.67 & $4.46^{*}$ & 0.39 \\
\hline Italy & .. &.. & .. & .. & 1.65 & $2.21 *$ \\
\hline Spain & $3.83 *$ & 0.32 & $5.99 *$ & 0.20 & $5.05^{*}$ & 0.24 \\
\hline Portugal & .. &.. & .. & .. & 2.41 & $2.98^{*}$ \\
\hline Austria & .. & .. & .. & .. & $5.81 *$ & $0.88 * *$ \\
\hline Finland & $2.78^{*}$ & $0.66^{* *}$ & $2.70 * * *$ & $1.22 * * *$ & $3.47 *$ & $0.83 *$ \\
\hline Germany (SOEP) & 0.67 & 1.02 & $4.06^{*}$ & 2.11 & $3.08 *$ & $1.82 *$ \\
\hline \multirow[t]{2}{*}{ United Kingdom (BHPS) } & .. & .. & .. & .. & $5.09 * *$ & 0.92 \\
\hline & \multicolumn{6}{|c|}{ Panel B. Labour market group } \\
\hline Total & $1.19 *$ & $1.11 *$ & $5.28^{*}$ & $0.91 *$ & $2.65 *$ & $1.22 *$ \\
\hline \multicolumn{7}{|l|}{ Gender } \\
\hline Men & $1.65^{*}$ & $1.25^{*}$ & $5.51 *$ & $1.49 *$ & $3.12 *$ & $1.43 *$ \\
\hline Women & 0.70 & $0.93 *$ & $4.97 *$ & 0.34 & $2.17^{\star}$ & $0.97 *$ \\
\hline \multicolumn{7}{|l|}{ Age } \\
\hline $25-34$ & $2.13 *$ & $1.55^{*}$ & 6.21 * & 1.41 * & $4.40 *$ & $1.65^{*}$ \\
\hline $35-44$ & 0.55 & $0.92 *$ & $2.70 * *$ & $0.78^{* * *}$ & $0.83 * * *$ & $1.06 *$ \\
\hline $45-54$ & 0.56 & $0.71 *$ & 1.47 & 0.17 & 0.81 & $0.72 *$ \\
\hline \multicolumn{7}{|l|}{ Educational attainment } \\
\hline Less than upper secondary & 1.09 & $1.29 *$ & 2.58 & 0.64 & $1.39 * * *$ & $1.24 *$ \\
\hline Upper secondary & 0.11 & $0.93 *$ & $6.87 *$ & 0.35 & $2.44 *$ & $0.96 *$ \\
\hline More than upper secondary & $1.43^{*}$ & $0.95^{*}$ & $3.03 *$ & $0.95^{*}$ & $1.97 *$ & $1.10 *$ \\
\hline \multicolumn{7}{|c|}{$\begin{array}{l}* * *, * * \text { Statistically significant at } 1 \% \text { level, } 5 \% \text { level and } 10 \% \text { level, respectively. } \\
\text { Not enough observations with at least one job change after a training spell. } \\
\text { (1) Estimates of the wage premium of participating in training in one additional year, obtained from the estimation of a wage equation controlling for individual fixed } \\
\text { effects, age, age squared, tenure, tenure squared, firm size, public sector dummy, occupation, permanent contract dummy, log of hours worked, log of hours worked } \\
\text { squared, the number of previous jobs, reason of last job change and interaction terms between country dummies, year dummies and date of interview. Training taken } \\
\text { with the current employer has been demeaned by subtracting job-match-specific means. Wage premia to training and formal education are estimated through a spe- } \\
\text { cification that simultaneously includes both variables. }\end{array}$} \\
\hline
\end{tabular}

Source: Own calculations based on the European Community household panel, waves 1 to 7 (1994-2000).

\section{Training and the perception of employment security}

In the literature, the term employment insecurity is generally used to denote the risk that a worker will experience a significant fall in earnings (and/or well-being) due to job loss or the threat of it (see Nickell et al., 2002; see also Green, 2003, for a more extensive concept). Job loss is intended to refer to separations that are involun- tary from the perspective of the worker. In practice, this means that employment security is composed of two elements: the likelihood of maintaining the employment relationship with unmodified working conditions (including pay) and the expected cost of job loss, which, in turn, can be seen as the product of the probability of job loss and its cost conditional on losing the job. 
The probability of experiencing an involuntary separation is a natural objective measure for the risk of job loss. A quick look at the data shows that workers who previously received education or training tend to separate less often from their employer against their will (Chart 3). However, the figures presented here must be handled with special caution. Indeed, the fact that lay-offs seem to be less frequent in the presence of training does not prove that training reduces the probability of being laid off. Providing an employee with training might be the consequence (and not the cause) of the employer's decision of not laying him/her off, which in turn might be dependent on individual characteristics (including unobserved ability). The natural framework to deepen this analysis and address this issue would be a standard hazard model with controls for individual fixed effects. Unfortunately, there is no cross-country comparable dataset with sufficiently long individual time series where two complete job spells can be observed for a large portion of the sample. For this reason, a formal multivariate analysis of separation rates cannot be devel- oped further in this paper. The route we follow here is rather to look at the impact of training on the subjective perception of employment security.

There is an increasing interest in the economic and sociological literature for subjective measures of job security (see OECD, 1997; Schmidt, 1999; Green et al., 2000; Burchell et al., 2001; Green, 2003). Subjective measures offer a synthesis of different aspects of employment security but they have the disadvantage of muddling up the expected cost of job loss (or threat of it) with subjective judgements on what level of job security would be desirable, which might be influenced by social norms as well as by attitudes towards risk, that may evolve during the lifecycle. These norms and attitudes might have little to do with objective security but — even worse - might affect the propensity to participate in training courses. Furthermore, subjective perceptions might be influenced by information disclosures that are only imperfectly correlated with real changes in objective risks. However, there seems to be a relatively good correspondence between

\section{Chart 3: Differences in involuntary separation rates between trained and untrained employees by labour market group and type of training}



(') Percentage-point difference in annualised rates of involuntary separations between trained and untrained employees. Involuntary separation rates are defined as the share of employees at date $t$ who have lost their job against their will by date $t+1$. Trained employees are defined as those who received some training between date $\mathrm{t}-1$ and $\mathrm{t}$. Data refer to persons aged 25-54 years.

Source: Own calculations based on the European Community household panel, waves 1 to 7 (1994-2000). 
subjective and objective measures of job insecurity, both at the individual and at the aggregate level (OECD, 1997, 2002, 2004; Wanner and Neumark, 1999; Farber, 2003). Subjective perceptions might also have an independent impact on workers' well-being: for instance, Burchell et al. (2001) report a strong link between perception of job insecurity and stress, and find that such a relationship becomes stronger as employees' exposure to insecurity increases. Last but not least, subjective feelings might affect the political economy of structural reforms.

Chart 4 focuses on the two-year variation of perceptions of job security (measured on a 1-6 Likert scale) and compares the share of employees for which their perception of job security has increased, decreased, or stayed the same, by country and training status. In all countries for which data are available except the United Kingdom, the percentage of workers who report a negative change in perceived job security is smaller in the case of those who received some education or training in the meantime than in the case of those who received none (with a 3 percentage point gap on average). Conversely, there is a less clear relationship between training and positive changes in job security. On average, about $32 \%$ of workers report to have experienced an increase in job security, independently from whether they have also received training.

The figures presented in the previous chart are, however, particularly difficult to interpret. Besides the general problems directly related to the use of subjective measures, a (temporary) improvement in the job match may simultaneously increase the amount of training individuals receive and their perception of job security. As done before, it is partially possible to sort these problems out by distinguishing between training with the previous employers and training with the current employers. In this case, however, the effect of training with the current employer cannot be identified by controlling for matchspecific effects. In fact, the quality of the job-match might not be acknowledged by workers at the moment of hiring and training provision by the employers might be one of the channels through which information is disclosed: receiving employer-sponsored training, employees realise that their employer does not intend to lay

\section{Chart 4: Changes in job security and formal education or training, by country}

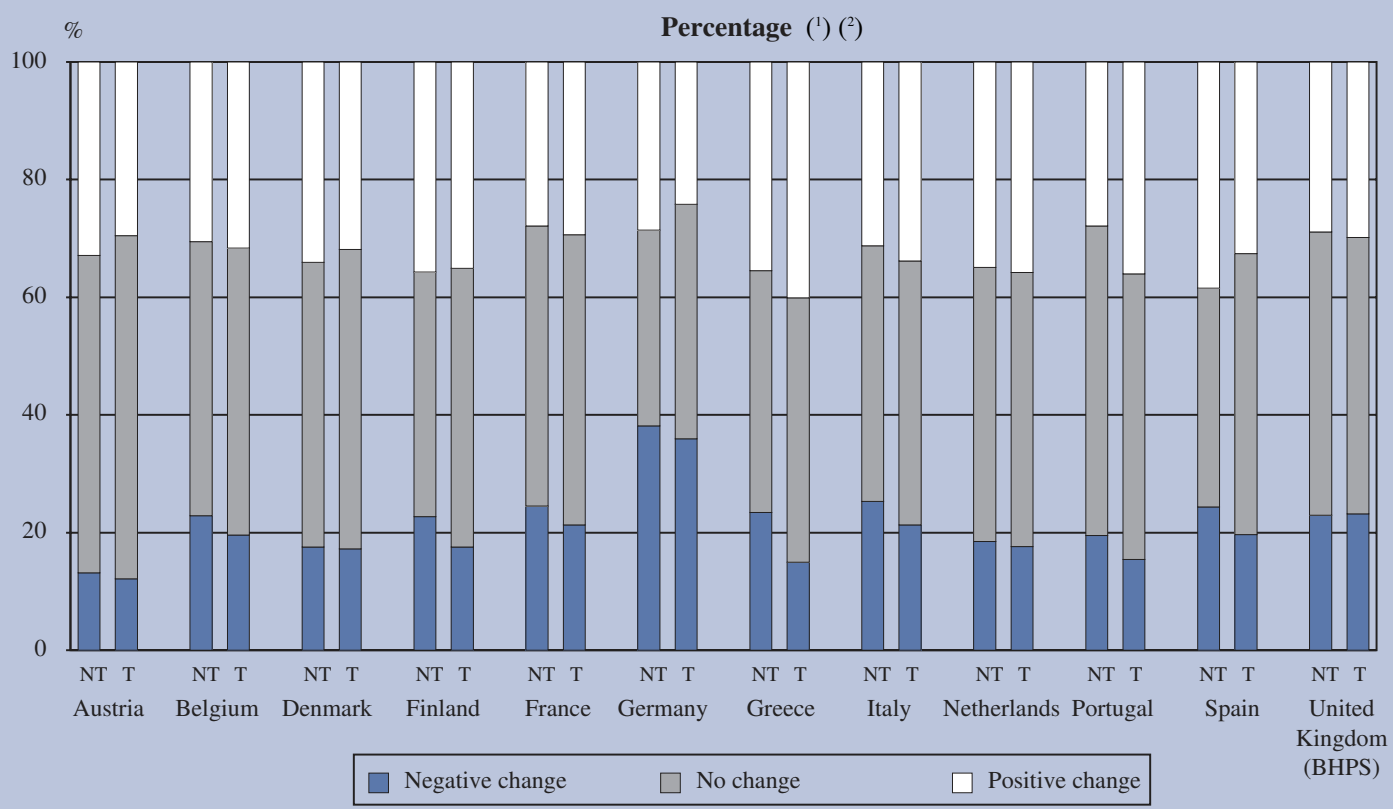

NT: Employees who received no training in the reference period.

T: Employees who received some training in the reference period.

(1) Two-year changes in the individual perception of job security.

(2) Data refer to employees working more than 15 hours per week and aged 25-54 years.

Source: Own calculations based on the European Community household panel, waves 1 to 7 (1994-2000) 
them off or, in the case of temporary workers, that their contract will be renewed or transformed, thereby improving their perception of job security, with no causal effect of training.

Following the literature on job satisfaction, one could estimate a fixed effect linear model (Heywood et al., 2002) or a fixed effect logit model (Winkelmann and Winkelmann, 1998), by collapsing the measure of job security into a dichotomous variable. However, neither of these methods is ideal, since in the first case the qualitative (or at least double censored) nature of the data is not taken into account, while in the second case a great deal of information is thrown away. In this paper, I choose to follow the first route and estimate the model in first differences, using observations at relatively distant dates - two years. The advantage of estimating the model in first-difference is that I can perform a sensitivity analysis by checking that results are not due to heterogeneity of returns at different levels of initial employment security. Accordingly, Table 2 reports estimates by labour market groups, while Table 3 reports estimates by lagged levels of employment security.

\section{Table 2}

Panel data estimates of the impact of training on security, by labour market group

\begin{tabular}{|c|c|c|c|c|}
\hline \multirow[b]{5}{*}{ Total } & \multicolumn{4}{|c|}{ Percentage $\left({ }^{1}\right)\left({ }^{2}\right)$} \\
\hline & \multicolumn{4}{|c|}{ Panel A. Formal education or training } \\
\hline & $\begin{array}{l}\text { Training taken with } \\
\text { previous employers }\end{array}$ & $\begin{array}{l}\text { Training taken with the } \\
\text { current employer }\end{array}$ & $\begin{array}{l}\text { Training taken with } \\
\text { previous employers }\end{array}$ & $\begin{array}{l}\text { Training taken with the } \\
\text { current employer }\end{array}$ \\
\hline & \multicolumn{2}{|c|}{ Model $1\left(^{3}\right)$} & \multicolumn{2}{|c|}{ Model $2\left({ }^{4}\right)$} \\
\hline & $1.7^{*}$ & $2.0^{*}$ & $1.5^{*}$ & $1.8^{*}$ \\
\hline \multicolumn{5}{|l|}{ Gender } \\
\hline Men & $2.0 *$ & $2.0^{*}$ & $1.6^{*}$ & $1.8^{*}$ \\
\hline Women & $1.0 * * *$ & $2.0 *$ & $1.3 * *$ & $1.9^{*}$ \\
\hline \multicolumn{5}{|l|}{ Age } \\
\hline $25-34$ & $1.1 * *$ & $2.0^{*}$ & $0.9^{*}$ & $1.7^{*}$ \\
\hline $35-44$ & $2.0^{*}$ & $1.7^{*}$ & $1.8^{*}$ & $1.6^{*}$ \\
\hline $45-54$ & $1.8 * * *$ & $2.2^{*}$ & $2.0 * *$ & $1.9 *$ \\
\hline \multicolumn{5}{|l|}{ Educational attainment } \\
\hline Less than upper secondary & $3.1 * *$ & $2.7^{*}$ & $3.1 * *$ & $2.5^{*}$ \\
\hline Upper secondary & $1.0 * * *$ & $1.7 *$ & 0.7 & $1.5^{*}$ \\
\hline \multirow[t]{4}{*}{ More than upper secondary } & -0.1 & $0.7 *$ & 0.0 & $0.6 * *$ \\
\hline & \multicolumn{4}{|c|}{ Panel B. Formal education $\left({ }^{5}\right)$} \\
\hline & $\begin{array}{l}\text { Training taken with } \\
\text { previous employers }\end{array}$ & $\begin{array}{l}\text { Training taken with the } \\
\text { current employer }\end{array}$ & $\begin{array}{l}\text { Training taken with } \\
\text { previous employers }\end{array}$ & $\begin{array}{l}\text { Training taken with the } \\
\text { current employer }\end{array}$ \\
\hline & & $1\left(^{3}\right)$ & & $2\left({ }^{4}\right)$ \\
\hline Total & 0.1 & $0.7 * *$ & 0.0 & $0.7 * *$ \\
\hline \multicolumn{5}{|l|}{ Gender } \\
\hline Men & 0.6 & $1.0 * *$ & 0.2 & $1.1 * *$ \\
\hline Women & -0.1 & 0.3 & -0.4 & 0.4 \\
\hline \multicolumn{5}{|l|}{ Age } \\
\hline $25-34$ & 0.6 & 0.0 & -0.2 & -0.1 \\
\hline $35-44$ & -0.7 & $1.2 * *$ & -0.7 & $1.2 * *$ \\
\hline $45-54$ & -2.7 & $1.4^{* * *}$ & -2.3 & $1.7 * *$ \\
\hline \multicolumn{5}{|l|}{ Educational attainment } \\
\hline Less than upper secondary & 2.4 & 0.9 & 1.9 & 0.7 \\
\hline Upper secondary & -0.4 & 0.2 & -1.0 & 0.3 \\
\hline More than upper secondary & -0.8 & -0.1 & -0.6 & 0.0 \\
\hline
\end{tabular}




\begin{tabular}{|c|c|c|c|c|}
\hline \multirow[b]{4}{*}{ Total } & \multicolumn{4}{|c|}{$\begin{array}{c}\text { Percentage }\left({ }^{1}\right)\left({ }^{2}\right) \\
\text { Panel C. Training }\left(^{5}\right)\end{array}$} \\
\hline & $\begin{array}{l}\text { Training taken with } \\
\text { previous employers }\end{array}$ & \multirow{2}{*}{$\begin{array}{l}\text { Training taken with the } \\
\text { current employer } \\
1\left({ }^{3}\right)\end{array}$} & $\begin{array}{l}\text { Training taken with } \\
\text { previous employers }\end{array}$ & $\begin{array}{l}\text { Training taken with the } \\
\text { current employer }\end{array}$ \\
\hline & Model $1\left({ }^{3}\right)$ & & \multicolumn{2}{|c|}{ Model $2\left({ }^{4}\right)$} \\
\hline & $1.6^{*}$ & $2.1 *$ & $1.6^{*}$ & $1.8^{*}$ \\
\hline \multicolumn{5}{|l|}{ Gender } \\
\hline Men & $2.1^{*}$ & $2.0^{*}$ & $1.8^{*}$ & $1.7^{*}$ \\
\hline Women & 0.8 & $2.1 *$ & $1.3 * *$ & $1.9 *$ \\
\hline \multicolumn{5}{|l|}{ Age } \\
\hline $25-34$ & 0.7 & $2.2^{*}$ & 0.8 & $2.0 *$ \\
\hline $35-44$ & $2.4^{*}$ & $1.6^{*}$ & $2.1 *$ & $1.4^{*}$ \\
\hline $45-54$ & $2.5^{* *}$ & $2.1^{*}$ & $2.6 * *$ & $1.8^{*}$ \\
\hline \multicolumn{5}{|l|}{ Educational attainment } \\
\hline Less than upper secondary & $3.0 * *$ & $2.8^{*}$ & $3.1 * *$ & $2.6^{*}$ \\
\hline Upper secondary & $1.1 * * *$ & $1.8^{*}$ & 1.0 & $1.5^{*}$ \\
\hline More than upper secondary & 0.1 & $0.8^{*}$ & 0.1 & $0.6^{*}$ \\
\hline \multicolumn{5}{|c|}{$\begin{array}{l}*, * * * * * \text { Statistically significant at } 1 \% \text { level, } 5 \% \text { level and } 10 \% \text { level, respectively. } \\
\text { (1) Estimates of the percentage impact on the average employee's perception of job security (measured on a 1-6 Likert scale) of participating in some training in one } \\
\text { additional year. The dependent variable is the two-year change in perceived job security. Estimates are obtained by OLS, adjusting standard errors for heteroskedas- } \\
\text { ticity of unkown form. } \\
\text { (2) Data refer to employees working more than } 15 \text { hours per week and aged } 25-54 \text { years. } \\
\text { (3) Controls are two-year differences of age and age squared, dummies for lagged level of job security, two year differences of the number of previous jobs, dummies for } \\
\text { voluntary or involuntary separation and country per year dummies. } \\
\text { (4) Controls are: two year differences of age, age squared, tenure, tenure squared, log wage, log of hours worked, dummies for public/private employment, the number } \\
\text { of previous jobs, lagged level of perceived job security, voluntary or involuntary separations in the two-year reference period and country per year dummies. } \\
\text { (5) Separate estimates for training and formal education are obtained by including both variables in the same specification. }\end{array}$} \\
\hline
\end{tabular}

Source: Own calculations based on the European Community household panel, waves 1 to 7 (1994-2000).

Two clear facts seem to emerge from Table 2 and Table 3. First, vocational training taken with previous employers has a positive impact on the perception of job security of all categories of workers (with the exception of those with the highest educational attainment) and, essentially, all levels of employment security $\left({ }^{1}\right)$. Given that these measures are partially forward-looking (that is, take into account the perceived risk of job loss), these results yield some support to the conjecture that returns to training might be positive even for those categories for which they do not show up in the wage level (conditional on being employed). Second, and more striking, training taken with previous employers has the greatest impact on perceived job security for those categories for which estimated wage premia are smaller. Conditional on

(1) Table 2 also reports estimates for the impact of formal education only, which is insignificant. Beyond the usual caution due to the fact that few education spells are observed in the sample, it must be taken into account that the effect of education is likely to materialise only in the long run. In the short run, individuals who have got a better diploma often start new careers by accepting better paid temporary contracts. changing job, for each year of previous training, employees without upper secondary qualification are estimated to increase their perceived job security by about $3 \%$, and employees aged from 35 to 54 years, by more than $2 \%$, with no smaller effect when only vocational training (excluding education) is taken into account $\left(^{2}\right)$.

As conjectured above, the fact that training seems to have a stronger impact on employment security than on wages (conditional on being employed) in the case of older prime-age workers can be easily explained through the effect of skill obsolescence on individual wages and productivity: in the presence of downward wage rigidity,

$\left.{ }^{2}\right)$ Care must be taken in interpreting these results, however, because the estimates are likely to be biased due to the inclusion of the lagged level of perceived job security, which is endogenous. Nevertheless, a quick look at the data shows that perceived job security exhibits a clear pattern of mean reversal; therefore it is likely that omitting the lagged level of job security would have induced an even greater bias. The application of instrumental variable techniques is made complex here by the lack of obvious instruments and is left for future research. 
Table 3

Estimates of the impact of training on security, by lagged level of job security

\begin{tabular}{|c|c|c|c|c|}
\hline & \multicolumn{4}{|c|}{ Percentage $\left({ }^{1}\right)\left({ }^{2}\right)$} \\
\hline & \multicolumn{4}{|c|}{ Panel A. Formal education or training } \\
\hline & $\begin{array}{l}\text { Training taken with } \\
\text { previous employers }\end{array}$ & $\begin{array}{l}\text { Training taken with the } \\
\text { current employer }\end{array}$ & $\begin{array}{l}\text { Training taken with } \\
\text { previous employers }\end{array}$ & $\begin{array}{l}\text { Training taken with the } \\
\text { current employer }\end{array}$ \\
\hline & Mo & $1\left({ }^{3}\right)$ & & $2\left({ }^{4}\right)$ \\
\hline \multicolumn{5}{|c|}{ Lagged level of job security $\left({ }^{3}\right)$} \\
\hline 1 & $28.3^{*}$ & $15.2^{*}$ & $18.9 * *$ & 6.8 \\
\hline 2 & 3.9 & 1.4 & 0.8 & 0.4 \\
\hline 3 & $7.0^{*}$ & $2.7^{*}$ & $6.2^{*}$ & $2.4^{*}$ \\
\hline 4 & $2.9 *$ & $2.1^{*}$ & $2.5^{*}$ & $1.9 *$ \\
\hline 5 & $1.3^{* *}$ & $1.8^{*}$ & $1.3 * *$ & $1.6^{*}$ \\
\hline 6 & $1.6^{*}$ & $1.4^{*}$ & $1.8^{*}$ & $1.3^{*}$ \\
\hline
\end{tabular}

Panel B. Formal education ${ }^{(5)}$

\begin{tabular}{|c|c|c|c|c|}
\hline \multirow[b]{3}{*}{ Lagged level of job security $\left(^{3}\right)$} & $\begin{array}{l}\text { Training taken with } \\
\text { previous employers }\end{array}$ & $\begin{array}{l}\text { Training taken with the } \\
\text { current employer }\end{array}$ & $\begin{array}{l}\text { Training taken with } \\
\text { previous employers }\end{array}$ & $\begin{array}{l}\text { Training taken with the } \\
\text { current employer }\end{array}$ \\
\hline & \multicolumn{2}{|c|}{ Model $1\left({ }^{3}\right)$} & \multicolumn{2}{|c|}{ Model $2\left({ }^{4}\right)$} \\
\hline & & & & \\
\hline 1 & -5.4 & -12.6 & -15.8 & $-21.1 * * *$ \\
\hline 2 & -5.3 & -6.9 & $-11.3 * * *$ & -5.5 \\
\hline 3 & 1.1 & -0.5 & -1.2 & -1.3 \\
\hline 4 & $3.9 * *$ & $2.0 * *$ & $3.0 * * *$ & $1.9 * *$ \\
\hline 5 & 1.1 & $1.5^{*}$ & 1.1 & $1.7 *$ \\
\hline 6 & -0.4 & 0.1 & -0.3 & 0.3 \\
\hline
\end{tabular}

Panel C. Training $\left({ }^{5}\right)$

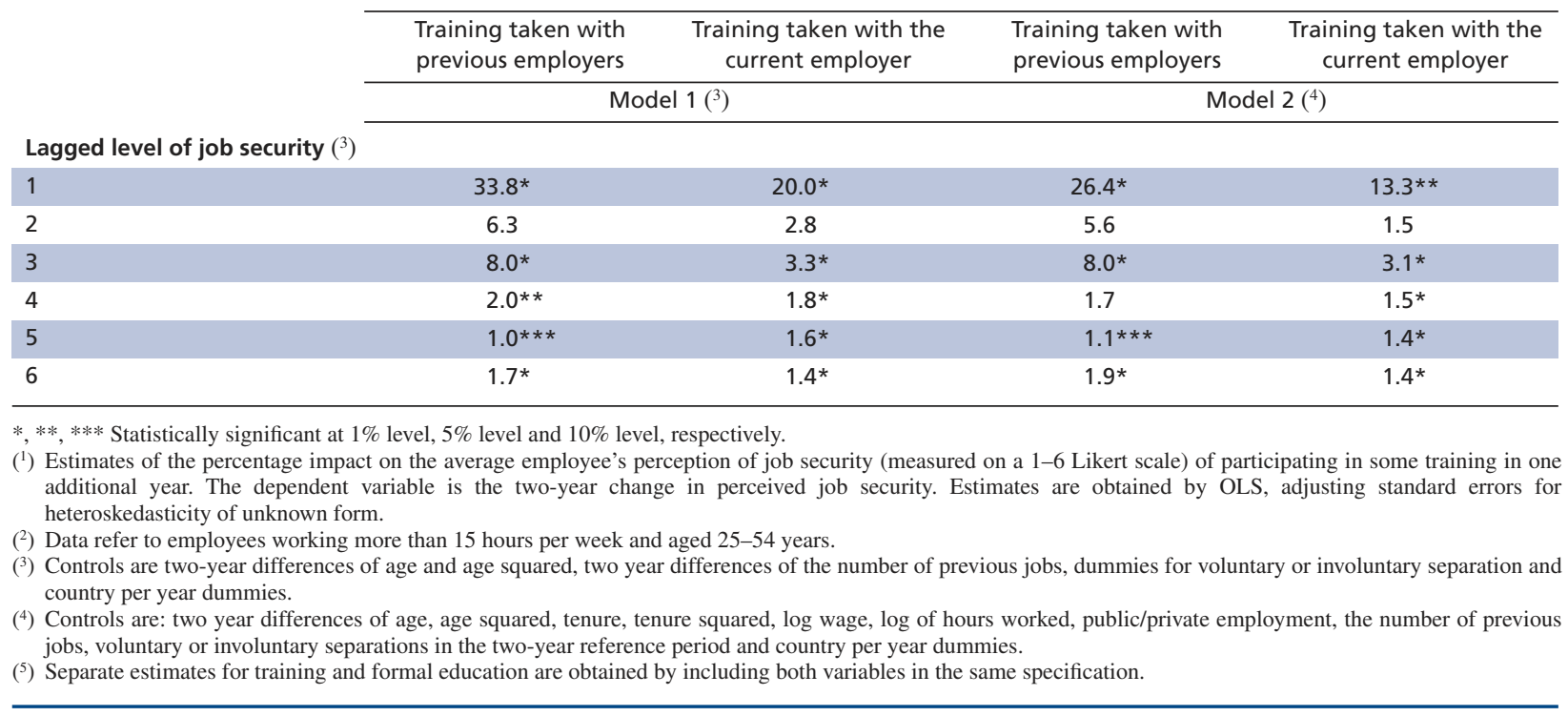

Source: Own calculations based on the European Community household panel, waves 1 to 7 (1994-2000). 
skill obsolescence compresses the wedge between productivity and wage, thereby increasing the risk of job loss without affecting the wage level conditional on keeping the job. In this case training is required to maintain workers' competences so that their productivity will match their wage. If the wage structure is compressed, a similar argument can be generalised to all low produc- tive workers (including, potentially, those with little or no qualifications). For instance, if the minimum wage is relatively high, a greater chance of being employed constitutes the main benefit from training for workers whose productivity would otherwise not match the minimum wage under all possible contingencies (Agell and Lommerud, 1997). 


\section{Are training investments inefficiently low?}

Overall, the previous section has shown that those workers, who do not seem to benefit from training through greater wages, can benefit from training by securing more stable employment prospects through lower job loss risk and/or greater chances to be re-employed quickly and in less precarious jobs. This is particularly the case for those categories (such as low-educated older workers) for whom their productivity-wage gap is more likely to be increasingly compressed — as they age — by companies' personnel policies and/or institutional arrangements (such as minimum wages). Once foregone income due to nonemployment spells is taken into account, training premia for all groups are likely to be large.

If private returns are high $\left(^{1}\right)$, why should governments adopt a proactive approach vis-à-vis training policy? The theory suggests that imperfections in labour, capital and training markets might interact in such a way to push economic agents (employers and employees) to invest in training less than the social optimum.

First, if labour markets are not perfectly competitive, firms may have an incentive to invest in general human capital (valuable also at other firms) to the extent that the market for skilled labour is less competitive than the market for unskilled labour, so that the training firm can afford to pay a trained worker less than its marginal product while still retaining the worker (see Acemoglu and Pischke, 1999a; Stevens, 1999). This is particularly the case for skills that cannot be useful to many other employers (Stevens 1994; 2001). Nevertheless, it might occur also in the case of fully general training due to asymmetric information and lack of certification (or lack

(1) In this paper we have confined our attention to workers' benefits. Nevertheless, many empirical studies show that adult training has a positive impact on productivity at the firm level and that part of these gains are appropriated by the firm (See Barron et al., 1999a; Dearden et al., 2000; and Ballot et al., 2001, for recent evidence for the USA, the United Kingdom as well as France and Sweden, respectively; see also Bartel, 2000, for a survey of previous studies). Total private returns are therefore even greater than the figures reported here. of recognition of qualifications), frictions and search costs, wage-bargaining institutions and outcomes, adverse selection affecting quits and lay-offs, or complementarity with specific investments (see Acemoglu and Pischke, 1999b). Symmetrically, these labour market imperfections reduce workers' incentive to invest in general training, insofar as they decrease workers' appropriability of its benefits. Since, in most conceivable situations, current employers cannot internalise the benefits from training that will accrue to future employers, by increasing the share of general training costs borne and benefits reaped by the firm, labour market imperfections are likely to generate non-optimal outcomes $\left({ }^{2}\right)$. By contrast, if pay scales reflected marginal productivity, as would be the case with perfect competition, workers would be able to internalise lifetime benefits from general training (Becker, 1975).

Second, workers may lack information on teaching quality and be unable to distinguish between different providers of educational services. Similarly, they might not be aware of what curricula are likely to yield the greatest return in the labour market. Furthermore, today's economic conditions may not reflect future demand for educated workers and the abilities to acquire and exploit skills may not be known to the prospective trainee before embarking in a course. These problems may seem less severe when firms act as training providers or intermediaries. In fact, employers might be more aware than workers of the required skills and curricula (although identification of training

(2) There are some caveats to this statement that need to be spelled out. To be true, this statement requires that quitting fees cannot be imposed on workers separating voluntarily after training (see Moen and Rosen, 2002) and that quit rates are not reduced by training. While the evidence seems to point to a positive relationship between training and the probability of quitting, at least in Europe (Brunello and De Paola, 2004), quitting fees are sometimes established in employment contracts, although their use is perhaps not widespread. Indeed, creating the institutional arrangements for pay-back clauses in employment contracts is one of the most effective policy actions that government can do in support of training investments (see Section 4.2). 
requirements might be a problem for some firms, particularly SMEs). There is nonetheless a conflict of interest between employers and employees insofar as the former prefer providing specific training while the latter prefer receiving general skills that can be re-sold in the labour market (Stevens, 1994; Barron, Berger and Black, 1999b). This conflict becomes particularly acute if training is not fully contractible. While the amount of training can be written down in a contract, its type and quality are less likely to be specified in a manner that is verifiable by third parties (e.g. courts of law, Malcolmson, 1997, 1999; Gibbons and Waldman, 1999). This may induce both the employee and the employer to behave non-cooperatively and invest in training separately without bargaining. In other words, the employee may refuse to treat the employer as a possible (and actually privileged) provider and the training provided by the employer will be entirely employerpaid. It can be shown (Acemoglu and Pischke, 1999a) that, under this condition, if the investments of the employer and the employee are perfect substitutes and returns to training are common knowledge, only one party will invest in general training (the one that benefits the most from that), and the amount of investment will depend on the marginal return to that party, being therefore not only sub-optimal but also lower than in the cooperative case wherein training contracts are enforceable. The intuition is that once the optimal investment of one party has been decided assuming noinvestment from the other party, the latter has no incentive to top-up the former's investment, despite the fact that both parties would gain from sharing the cost of investment and invest more. The investing party might be the employer if there are labour market imperfections compressing the structure of wages over the skill dimension. If this party is the employer, the greater the monopsony power it has on its skilled workers (the wider the labour market imperfections) the greater the amount of general training provided. From a qualitative point of view, this argument can be extended to all cases of imperfect substitution, except when both parties' investments are fully complementary, but it is difficult to think about cases where this occurs in practice.

Third, human capital cannot be used as collateral (Becker, 1975). Moreover, individual human capital investment is often indivisible and therefore the risk associated to it cannot be diversified. Finally, although in a perfect information world, trainees could buy insurance to shelter against the risk, in practice, a private insurance market is unlikely to work in a proper way due to the unobservability of the trainee's effort and the size of human capital investments (the level of individual liability required to avoid adverse selection would be too high, see Stevens, 1999). The employer can partially relax the employee's credit constraint to the extent that the employee accepts a lower wage during the training period. However, there is a limit to the extent to which small knowledge-intensive firms can borrow to finance training expenditures using physical capital as collateral. Furthermore, if workers cannot borrow at a competitive interest rate, the demand for training may remain below the social optimum, since in order to smooth consumption over time the employee cannot accept large wage cuts (see Acemoglu and Pischke, 1999a). Moreover, the wage can be lowered in exchange of training provision only if the latter is contractible. Nevertheless, as said, if employers have some market power over their own skilled labour, they may have an incentive to bear part or all the cost of training without asking for a reduction in wages. As in the case of non-contractibility of training, if workers are severely credit-constrained, labour market imperfections are likely to increase training provision since they increase firms' investment with only limited effects on workers' investment, which is already low, thereby easing the negative impact of capital and training market imperfections.

The interaction between different market failures is a powerful explanatory tool for the empirical evidence. The theory points to the fact that if imperfections in the training or capital markets are not too severe, the negative effect of labour market imperfections on workers' willingness to invest will dominate, since workers can better internalise lifetime benefits from training than their employers (see Stevens, 1999, for a simple graphical explanation). Conversely, if we found that the smaller the degree of competition in the labour markets the greater the amount of training, this could be interpreted as evidence that training and capital market failures affecting training outcomes are pervasive $\left(^{(}\right)$. This is indeed what seems to emerge from the empirical literature, at least insofar as European countries are concerned. For instance, Bassanini and Brunello (2003), in their most cautious estimate, suggest that in the European Union an increase of 1 percentage point in the training premium would induce a 3-4\% fall in the share of employees undertaking general training, resulting from a reduction of $2.5-3.5 \%$ in employer-financed training

(1) Alternative explanations remain, however, available (see Agell and Lommerud, 1997; and Moen and Rosen, 2002). 
and an almost negligible increase in self-financed training. Moreover, Brunello and Gambarotto (2004) estimate larger effects for the United Kingdom. They find that a $10 \%$ increase in the density of local economic activity - which can be considered as a proxy of the level of local labour market competition - entails a $20 \%$ fall in average training provision. Similar results are found by Arulampalam et al. (2004b) who estimate the impact of the introduction of a minimum wage on the level of training provision in the United Kingdom, while the US literature on minimum wages and training is less conclusive (see Neumark and Wascher, 2001; and Acemoglu and Pischke, 2003). 


\section{The quest for efficient training policies}

Insofar as market failures are responsible for suboptimal training provision, a first-best approach would be to overcome them through structural reforms. However, some of these failures are due to 'natural' imperfections of certain markets $\left({ }^{1}\right)$ and effective reforms to overcome them have not been proposed yet. Furthermore, other imperfections are induced by institutions and policies that do not concern primarily training outcomes (e.g. those affecting the wedge between wages and productivity such as minimum wages; see Acemoglu and Pischke, 2003), whose reform cannot be undertaken without a careful evaluation of other relevant trade-offs. A secondbest approach is to increase the economic incentives to invest in education and training, through fiscal policy and institutional arrangements favouring cost-sharing among private parties. However, policy design is crucial, since some of the possible sources of market failure (e.g. lack of contractibility of training quality) can equally lead to policy failures, with the risk of large deadweight losses and heavy burdens for the public budget.

This section reviews the experience of OECD countries with various second-best approaches to surmount financial and economic barriers to the provision of and participation in adult education and training. However, great care must be exerted when drawing general conclusions from this type of exercise for three reasons. First, strictly speaking, the case in favour of public intervention has not been made in a conclusive way. Second, in most cases, public policies focus on formal education and training. This entails a risk of inefficient substitution between formal and informal training. This risk must be taken into account in the case of policies affecting employers' incentives to provide formal training, to the extent that informal training is more likely to be

(1) The lower level of competition in the market for workers who have acquired imperfectly transferable skills is the easiest example. In contrast to purely general skills, imperfectly transferable skills are not valuable at every firm. Therefore, although training in these skills increases potential job opportunities for the worker, finding them may require a long and costly search process. employer-paid, since it imparts competencies that are less easily signalled to the external labour market (making informal training, de facto, firm-specific, see Acemoglu and Pischke, 1999b; and Barron, Berger and Black, 1999b). Third, policies are discussed here in a partial equilibrium framework - that is, without considering the effect of the distortions induced by fund-raising schemes required to finance training policies. Fourth, and perhaps more importantly, the analysis is essentially based on deductive arguments derived from the empirical results of the previous sections. In fact, there are only few empirical evaluations of existing schemes and, with few exceptions, those available are limited to descriptive statistics and do not build up counterfactuals against which a rigorous assessment could be made. For these reasons, it is only possible to discuss the problem each specific policy can try to address and, to a limited extent, whether it has been implemented in a consistent way. It is not possible to make a more general assessment of whether each intervention has been excessive, insufficient or just right vis-à-vis the target.

Since the 1960s, policies were formulated to address, first and foremost, perceived rigidities on the supply side that interfered with adult education. The underlying assumption was one of substantial economic and social demand for adults to return to formal education. Thus, the objective of recurrent education was to improve learning opportunities for individuals by enhancing the capacity of the formal education sector to accommodate those wishing to return to education. However, recurrent education never emerged as an enduring widespread practice, in part because its associated costs were never adequately funded.

More recently, greater emphasis has been devoted to the demand side. This new emphasis has entailed a shift in the target of public policy from providers and systems geared to provision of education and training with relatively homogeneous content to the demand of individuals and employers for more heterogeneous learning out- 
comes. In other words, in contrast to children in initial education, learning objectives of individual adults are ever-changing and very heterogeneous so that such needs can best be met through a more differentiated arrangement of providers and courses than the delivery mode characterising initial and recurrent education. As a consequence, policy strategies to increase human capital accumulation of adults have shifted from direct subsidisation of external (public or private) providers of training services to co-financing schemes intended to increase incentives for employers and/or individuals to invest in more specific education and training. The shift towards this policy approach is based on three general principles:

- in most societies, because of budget constraints, public authorities alone cannot provide the necessary financial resources for lifelong learning;

- as lifelong learning generates considerable private returns, employers and employees should finance most of its costs; and

- greater reliance on market forces could strengthen the incentives both for learners to seek more efficient learning options and for providers to achieve higher levels of efficiency.

Co-financing mechanisms - i.e. schemes that channel resources from at least two parties among employers, employees and governments - can be designed so as to increase incentives to invest in human capital for employers, for individuals or for both.

Since the primary reason for which employers might invest in training less than the socially optimal amount is that current employers might not be able to internalise benefits from training that will accrue to future employers, tax arrangements or grant schemes for enterprises can be used to tackle aggregate under-investment. By modifying the marginal cost of training, these schemes may raise employers' supply towards the socially optimal level. These schemes can also be complemented by policies favouring cost-sharing between employers and employees, such as regulatory provisions for pay-back clauses and time accounts, to the extent that training market imperfections are not too strong. In fact, costsharing is unlikely to occur if the content and quality of training are not contractible.
For workers who have less frequent opportunities to receive employer-sponsored training, it is likely to be difficult to target policies focusing on employers' incentives in an efficient way (see OECD, 2003a). Individualbased demand-side policies (such as loan and subsidy schemes), by relaxing individual borrowing constraints and increasing expected rates of return, can thus play a role. However, they require information that workers often do not have. In addition, portability of skills must be assured, particularly in the case of training not delivering formal diplomas. As a consequence, financial incentives must be accompanied by adequate framework conditions. Even in this case it might be difficult to target with precision certain workers (such as workers with poor literacy skills). Strengthening delivery of initial education emerges therefore as a necessary complementary policy instrument.

The remainder of this section provides a survey of innovative co-financing strategies put in place by OECD countries to overcome the economic and financial barriers to invest in adult learning as well as framework conditions necessary to make these strategies effective.

\subsection{Incentives for firms}

\section{Tax arrangements for enterprises}

Tax-based schemes have the advantage of building on existing institutional arrangements for taxation, allowing them to be generally and immediately applied with limited implementation costs; for the same reason they have the disadvantage of being difficult to target precisely. When these schemes are targeted, they may induce inefficient substitution across groups (see below). As a consequence, tax-based schemes typically leave total freedom to choose training content and participants to firms.

'Train or pay schemes', which establish training levies to be paid by employers who do not train, are a route to tackling free-riding and under-provision that was popular in the 1970s. France first adopted this approach with the loi de 16 juillet 1971, which introduced a minimum training expenditure and required that each firm pays, as a levy, an amount equal to the difference between this legal minimum and its actual training expenditure. The law initially required employers to invest an amount equal to $0.8 \%$ of total payroll. That requirement has risen gradually to $1.6 \%$ in recent years, being even higher for temporary work agencies and workers with fixed-term contracts. A number of other countries 
including Australia, the Quebec province of Canada, Korea and the United Kingdom adopted similar provisions in subsequent years, but abandoned them later. Today, only Quebec is still following the French model, while a number of other countries have introduced levy/ grant systems where all employers pay the levy independently of their training expenditure and can then recover part or all of it by applying for grants from specific funds financed through the levy (see below).

Train-or-pay schemes confront employers with a financially neutral choice between training (and not paying the tax), or not training (and paying the tax). Funds collected this way are then distributed to firms in the form of additional grants. Strictly speaking, firms receive no automatic subsidy, since grants are not necessarily awarded. 'Train-or-pay' levies, however, are equivalent to schemes where there is a tax of a given percentage of payroll independent of training expenditures, a $100 \%$ automatic subsidy of training expenditures up to that percentage of payroll, and an additional grant awarded through case-by-case analysis of training projects.

The problem with these schemes is that what counts for individual or employer's decisions to invest in training is the difference between marginal expected benefits and marginal training costs. Train-or-pay schemes focus on total cost, thereby inducing large deadweight losses. This is immediately evident in the case of firms that would have spent up to the legal minimum anyway, since these firms enjoy a windfall without increasing their incentives to invest in training. However, by covering total costs up to a pre-determined ceiling, 'train or pay' levy/grant schemes also 'overpay' the increase in training investment they induce on the part of firms that would have spent less than the legal minimum in the absence of the scheme.

In other countries - including Austria (in 2000), Italy (in 2001), Luxembourg (in 1999) and the Netherlands (in 1998) - fiscal deductions represent a matched contribution from the government that never covers the totality of training costs. In these countries employers are allowed to deduct more than $100 \%$ of the cost of training from turnover when determining taxable income (Table 4). The extra-deduction (that is the actual subsidy) amounts to $10 \%$ of training expenditures in Luxembourg, $20 \%$ in Austria and the Netherlands and up to $50 \%$ in Italy.

The main differences across countries concern the type of expenditures that are eligible for deduction. In fact, although internal training expenditures are more difficult to define in a clear and transparent way, covering only external expenditures might lead to inefficient substitution of external for internal training, with little or no impact on the overall volume. While in the Netherlands and Luxembourg both external and internal training are covered by these schemes, in Austria internal training expenditures are eligible for deduction only if provided by an in-company training institution (or separate legal entity). The Italian case is more complex since before the 'Tremonti-bis' Act (Legge 383/2001), training expenditures were not treated as costs of business. As a consequence, the law has introduced a true extra-deduction only for those expenditures that are normally counted as operating costs (such as trainees' and internal trainers' wages) and has only partially caught-up with the legislation of most other countries for other types of training expenditures. Another key issue is whether only direct costs are eligible for the extra tax deduction or if trainees' wages are also considered. For instance, in the Italian scheme the latter are included in up to $20 \%$ of the payroll, while in the Dutch scheme they are generally excluded. When trainees' wages are excluded, it can be expected that these types of incentives tend not to be neutral with respect to trainees' characteristics and favour those for whom employers' opportunity cost of training (in terms of wage plus foregone productivity) is lower, such as inexperienced newly-hired workers. Nevertheless, most of these schemes are very recent and therefore there are no rigorous evaluations of their impacts.

Tax deductions provide no incentive to increase training if employers do not expect positive profits in a given fiscal year. This is particularly undesirable insofar as it is precisely during slack periods that the economic cost of foregoing production during training is lowest. To address this issue, Austrian law provides that $6 \%$ of all training expenditures incurred in a given year, which cannot be deducted in that year, can be either paid out to the firm or subtracted from the firm's tax liability in the previous or subsequent year. Similarly, deductions of training expenditures can be postponed for up to 4 and 10 years in Italy and Luxembourg, respectively, if taxable income is negative. A Swedish survey reports that employers would expect to increase training expenditures significantly if similar arrangements were introduced in their country (Håkanson, Johanson and Mellander, 2002).

Targeting certain types of firms whose training supply is particularly low (such as small firms) through additional 
Table 4

Corporate tax deductions for training expenditures in selected OECD countries

\begin{tabular}{|c|c|c|}
\hline Country & Main provisions & Restrictions \\
\hline Austria & $\begin{array}{l}\text { Deduction of } 120 \% \text { of CVT cost from turnover. Alternatively, } \\
\text { deduction of } 6 \% \text { from previous or subsequent year's tax } \\
\text { liability (since 2002). }\end{array}$ & $\begin{array}{l}\text { For externally provided CVT that is relevant to company } \\
\text { interests (since 2000); for internal CVT organised by a } \\
\text { separate in-company training unit (since 2003). }\end{array}$ \\
\hline Italy & $\begin{array}{l}\text { Deduction of } 150 \% \text { of CVT cost from turnover (since 2001). If } \\
\text { no taxable income in a given year, deduction can be } \\
\text { postponed for up to four years. }\end{array}$ & $\begin{array}{l}150 \% \text { deduction only for expenditures normally counted as } \\
\text { operating costs (such as trainees' and trainers' wages). } \\
\text { Deduction may include up to } 20 \% \text { of payroll. }\end{array}$ \\
\hline Luxembourg & $\begin{array}{l}\text { Deduction of up to } 110 \% \text { of CVT cost from turnover (since } \\
\text { 1999). If no taxable income in a given year, deduction can be } \\
\text { postponed for up to } 10 \text { years. }\end{array}$ & \\
\hline Netherlands & $\begin{array}{l}\text { Deduction of } 120 \% \text { of CVT cost from turnover (since 1998). } \\
\text { More generous schemes for small firms and low-educated } \\
\text { workers. }\end{array}$ & $\begin{array}{l}\text { Only for training that is relevant to current functions of } \\
\text { trainee. In the case of internal training, only cost of time } \\
\text { spent by trainer can be deducted, with the exception of } \\
\text { training for previously unemployed workers (aged } 23 \text { years } \\
\text { or older) that are trained to basic qualification level, for } \\
\text { which employers can deduct also workers' wages and } \\
\text { indirect training costs such as those due to extra supervision } \\
\text { and modification of production plans (since 2002). }\end{array}$ \\
\hline
\end{tabular}

CVT: Continuous vocational training.

Source: OECD Secretariat on the basis of information supplied by the countries in question.

corporate tax deductions is feasible - at least in principle. Conversely, targeting specific worker groups may involve undesirable substitution effects. For example, Leuven and Oosterbeek (2004) show that the $40 \%$ extradeduction to train workers aged 40 years or older, introduced in the Netherlands in 1998 and recently abolished, induced significant substitution between training workers above the age threshold and training workers immediately below it. Once the substitution effect is taken into account, the overall effectiveness of the scheme becomes questionable.

Summarising, it can be tentatively concluded that an effective use of tax incentives to reduce the possible firms' under-investment in training requires extradeductions of training expenditures rather than 'train or pay' schemes, which involve a large deadweight cost. It is also desirable that these deductions can be postponed for several years if companies have no positive profits in the year they make the expenditure.

\section{Grant schemes and special funds for enterprises}

In 'train-or-pay' schemes, the levy is payable only if the firm's own training effort falls short of a legal minimum. By contrast, other levy/grant schemes imply that all companies pay a training levy — normally as a percentage of payroll - after which they can try to recover (part of) their payment through applications for grants to fund training. Grants do not tend to reflect company payments and therefore allow redistribution of funds towards predefined priorities.

Prime examples of this kind of levy/grant schemes at national level are found in Spain and Belgium. In Spain, employers pay $0.7 \%$ of payroll into a training fund administered by a Tripartite Training Foundation, where sectoral commissions staffed by employer and trade union representatives decide and manage training grants. In Belgium, a nationwide collective agreement, which was later converted into a law, requires employers to pay $0.25 \%$ of payroll into a training fund, a sum that can be topped up by branch-level collective agreements.

In addition to systems established by nationwide legislation, a number of countries have sectoral training levies established through branch-level collective agreements. For example, the Netherlands and Denmark have followed this route, with half of the Dutch and one third of the Danish workforce currently covered by sectoral levies and training funds (Gasskov, 2001). The average contribution rate in the Netherlands is $0.5 \%$, but with considerable variation across branches. Other countries, such as France and Belgium, have set up many sectoral funds on top of their national levy regulation. Similarly, 
the USA has compulsory schemes for making contributions to training funds in a few sectors or companies with high trade union density, such as the automotive industry. Typically, there is a bipartite or tripartite joint governance of the training funds financed through levy schemes (see Ok and Tergeist, 2003, for detailed examples), but there are some exceptions (notably Korea, where the public employment service administers the respective fund).

Apart from programmes financed through specific levies, most OECD countries (e.g. European Union countries, the Czech Republic, Korea, Japan, Mexico, Poland and the USA) have some programmes for subsidising company training expenditures that are financed out of the central government budget. However, grant schemes, whether financed through a special levy or out of the normal budget, have the drawback of high administrative costs. Also, there is a trade-off between allowing flexibility to accommodate demand-driven needs and constraining the scheme via rigid eligibility criteria to ensure transparency and minimise abuse. Furthermore, it has been argued that small firms may find it comparatively more costly to meet all the conditions required to file grant applications (Gasskov, 1998).

\subsection{Institutional arrangements to enable cost-sharing}

\section{Pay-back clauses}

In principle, statutory or contractual pay-back clauses can specify that a worker leaving the firm within a specified period after an education or training spell has to agree to reimburse at least part of the training costs incurred by the employer. Pay-back clauses are intended to mitigate two of the market failures potentially affecting education and training. On the one hand, they limit the extent to which future employers can appropriate the benefits from current employers' investments in training through the poaching of trained employees, thereby allowing current employers to recoup the cost of training by setting wages below productivity after the training spell. On the other hand, they permit workers to share the costs of training even in the presence of serious individual credit constraints, by de facto borrowing from their employers with low default risk.

In Luxembourg, if no collective agreement specifies differently, the loi cadre 22 juin 1999 establishes a payback clause covering part of the expenses paid by the employer in the 3 years preceding a voluntary quit, except when the latter is due to the employer's misconduct. Similar provisions apply also in the case of lay-offs for serious fault by the employee. In many countries (e.g. Austria, the Czech Republic, Germany, Korea, Italy, the Netherlands, Norway, Switzerland, and the USA), payback clauses are not established by the law but are permitted within certain limits in individual contracts or collective agreements.

Even where pay-back clauses are legal, their application might be limited due to problems of contractibility of training contents that discourage an effective sharing of training costs (see the previous section). Pay-back clauses may be well suited for formal education or external training programmes, leading to certification, since training-related expenditures, training content and quality as well as the value of being trained for the employee (i.e. the market price for the skills acquired through education or training) can be easily assessed. However, this is not the case for many other types of training. For instance, in Italy pay-back clauses have been used particularly for newly hired managers enrolling in MBA programmes. Similarly, statutory provisions in Luxembourg apply only to training leading to certification and in the context of an agreed firm training plan, while in Germany courts have found contractual pay-back clauses admissible only if the quitting employee can benefit from the content of training in other jobs. Nonetheless, Bellmann and Düll (2001) report that about $15 \%$ of German enterprises apply pay-back clauses. Pay-back clauses might also be more viable if stipulated through collective agreements, since trade unions are in a better position to monitor training contents than individual workers. In the Netherlands, for example, many collective agreements establish pay-back clauses (Waterreus, 2002).

\section{Apprenticeships}

Apprenticeships are another type of contract that allows sharing the cost of training in a similar way to pay-back clauses. In many countries, apprenticeships represent a longstanding system of combining training and employment so that people entering an occupation can receive instruction in the specific skills needed while working in that particular occupation. Common features of apprentice contracts are that they last for a duration specified at the start, apprentices are paid less than their productivity during most of the period covered by the contract, and a recognised qualification is delivered at the end, with the apprentice receiving a substantial wage increase if he/she 
stays with the same firm. These features make apprentice contracts a valid option even for non-contractible training (Malcomson, Maw and McCormick, 2003). Similarly to contracts involving pay-back clauses, employers can recoup the cost of training by paying workers less than their marginal product in the final stage of the apprenticeship. But contrary to pay-back clauses workers can quit before the end of the contract without penalty except that, if they do, they do not receive the final certification. For this reason, workers have an interest to stay at least until the end of the apprenticeship, but firms have an interest to provide good-quality training to minimise quits. To the extent that there are no age limits, apprentice contracts can be successful also within groups of low-qualified mature workers. For instance, in Australia, since all age restrictions were removed from apprenticeships and traineeships in 1992, individuals aged 25 years and over have accounted for the majority of new apprenticeships, but this strong growth has not come at the expense of younger apprentices whose number also rose (OECD, 2003c).

\section{Working-time and training-time accounts}

In many OECD countries, increased flexibility of working-time arrangements, featuring inter alia the annualisation of working hours or long hours-averaging periods, has led to the creation of working-time accounts for individual employees. The basic idea behind working-time accounts is that over a certain period of time an employee is able to work longer or shorter hours than the standard working time established by the employment contract, and thereby accumulate working-time credits or debits in an individual account, which are later compensated for by additional free time or work. As a result, they can be used to share training costs in a similar way to pay-back clauses, except that with working-time accounts workers de facto anticipate their share of the cost. Additionally, they may facilitate overcoming those constraints posed by time constraints, which are one of the most important factors preventing workers from taking the desired amount of training (see OECD, 2003a).

Already in 1994, France adopted a law introducing a 'time-saving account' for employees (compte épargnetemps). This account allowed workers to accumulate time credits over a number of years - using, for example, overtime hours or reduced working hours in the framework of the move towards the 35-hour week - and subsequently decide whether to make use of this 'time capital' for, inter alia, early or gradual retirement, the takeup of part-time work, or training leave. So far, the use of the account for training has occurred only in a small minority of cases. However, legislation passed in 2003 urges social partners to negotiate about the use of working-time accounts for training purposes.

In the Netherlands, about one quarter of large collective agreements establish the possibility of saving spare time for educational purposes. Compensating accumulated overtime hours in the form of extended leave at a later date is a very common practice in Denmark (EIRO, 2001). In a recent employer survey in western Germany (excluding Berlin), $11 \%$ of all companies that offer training — primarily the larger ones — and that operate working-time accounts offer the option of using the accumulated working-time capital for training purposes (Dobischat and Seifert, 2001). Such 'training time accounts' can be fed through accumulated overtime hours or through special employer bonuses. As in the case of other instruments that facilitate a sharing of training costs between employers and employees, time accounts are likely to be effective only to the extent that training is contractible. As such, their use is likely to be limited when training opportunities must be chosen by the employee within the training plan of the company, except when the latter has resulted from an effective negotiation among social partners (see below).

\subsection{Incentives to increase individual demand}

Most individual-based demand-side schemes try to address simultaneously individual borrowing constraints and low or uncertain rates of returns for specific groups who typically do not receive employer-sponsored training $\left({ }^{1}\right)$. The main rationale for individual-based demand-side schemes is that they can be more precisely targeted than financial incentives for employers (or training institutions), while providing the individual with a greater range of training choices.

\section{Subsidies}

Most countries have schemes to subsidise directly individuals enrolling in training courses. Subsidies are flexible instruments that can target specific groups. However, they often require careful attention to framework conditions in order to work properly (see below).

(1) The only exception is loan schemes. However, the UK experience suggests that loan schemes may have only limited appeal because adults tend to be more reluctant than younger persons to finance learning through loans, perhaps due to existing debts (e.g. home mortgages), family responsibilities, or shorter payback periods (Callender, 2002). 
Three issues are key in the economic analysis of subsidies to individuals: (i) what the subsidy covers: fees and/or living expenses and/or foregone income; (ii) what requirements individuals must satisfy to qualify for the subsidy; and (iii) to what extent individuals are free to choose the type and timing of training as well as the training provider.

There is an evident tension between, on the one hand, increasing training demand and individual choice without boosting costs and, on the other hand, conveying adequate information about training quality to individuals and preventing possible abuses. In principle, the former objective would require allowing the supply of training services to respond freely to demand through free entry and course innovations. However, a certain amount of time-consuming screening, monitoring and control is called for by the second objective. In practice, subsidy schemes that give total freedom of choice to individuals are rare (perhaps only the UK individual learning accounts fall into these categories, but their evaluation suggests that excessive freedom made the system liable to fraud and abuses; Owens, 2001; York Consulting, 2002). In most cases governments compromise between these conflicting objectives by constraining training choices within a more or less wide menu and adjusting the subsidy rate accordingly. For instance, training vouchers (used, for example, in certain regions of Italy and Switzerland) typically leave free individual choice within courses offered by accredited training providers.

In some cases, subsidies target explicitly specific segments of the population. For instance, in Germany, the government subsidises training expenditures of workers aged over 50 and workers with no vocational qualification (or those with vocational qualifications but who have been in semi-skilled or unskilled occupations for more than four years). Nevertheless, except within certain leave schemes (see below), direct training subsidies seem to be unable to radically increase training, to the extent that training outcomes are not inefficiently low because of relatively mild capital market failures. Only in a few cases, in fact, are training subsidies intended to replace income for individuals who pursue full-time learning activities. Since government contribution is relatively small, most of the burden remains on the individual, who usually has either no adequate incentives (e.g. in the case of labour market imperfections) or no adequate means (e.g. in the case of capital market imperfections) to bear it. In this respect, the evolution of the indi- vidual learning account established by Skandia - a Swedish private insurance company — offers insights into the extent to which the impact of a subsidy scheme on disadvantaged groups depends on the scale of contributions from third parties. Within this scheme workers can save up to $10 \%$ of their salary in a saving account, with the company offering a one-to-one match. The company has gradually increased its contribution up to a three-to-one match for poorly qualified and lower paid employees, raising dramatically the participation of this group that was severely under-represented when the scheme was first introduced (see OECD, 2003c).

\section{Tax incentives}

While expenditures for formal education usually can be deducted from personal income taxes, tax systems are typically more restrictive in their treatment of training expenditure by individuals. Generally, such expenditure cannot be deducted from the taxable income of individuals, except under circumstances in which such training is required for the job they currently hold. Moreover, when employers provide financial support for training that leads to recognised qualifications, the expenditure by the employer may be treated as taxable income to the learners.

Some initiatives have been taken to relax these restrictions. For instance, starting in 2003, Austrian legislation will allow individuals to deduct costs related, not only to training required for their current job, but also for training that equips them to change jobs or enter a new profession. In spite of the interest for these policy innovations, it must be noted that tax deductions of current individual expenses for education and training are likely to be effective only for short and/or part-time training as well as for high-wage employees, since individuals can only make use of these deductions if they earn enough in a fiscal year to be liable to pay taxes. There is no such limitation only when tax deductions apply to saving schemes to finance future learning activities (e.g. individual learning accounts and leave-saving schemes).

\section{Training leaves}

Meeting the training needs of employed individuals may frequently require them to stop working for a considerable period of time. In many OECD countries access to training under these circumstances is facilitated by statutory or contractual training leave schemes that guarantee employees the right to return to their jobs after completing the training course. 
Simulation exercises suggest that foregone income depresses individual rates of return to full-time adult education more than any other factor (OECD, 2003b). This implies that subsidy schemes need to compensate in part for foregone income to reach low-income/lowwealth labour force segments, in particular when training requires a prolonged period of service (and wage) reduction. For this reason, in some countries, special training leave subsidies (Table 5) are available, particularly to cover living expenses or partially replace foregone income. In Germany, a special subsidy also exists for part-time workers participating in training. Other policy alternatives include tax incentives for saving accounts, but they have been rarely established in practice by governments. One exception is the possibility for Dutch employees, introduced in 2001, to join a 'leavesaving scheme', which allows them to set aside up to $10 \%$ of their gross yearly wage in a saving account with privileged tax treatment to finance a personal leave, with training or studies being one of the declared aims of such leave. Provisions for training leaves are also often included in collective agreements, even in countries where statutory schemes do not exist (such as Australia and Portugal).

Table 5

Training-leave schemes in selected OECD countries

\begin{tabular}{|c|c|c|c|c|c|c|}
\hline Country $\left({ }^{1}\right)$ & Eligibility & $\begin{array}{c}\text { Subsidies } \\
\text { provided to }\end{array}$ & Subsidy ranges & $\begin{array}{c}\text { Funding } \\
\text { mechanism }\end{array}$ & $\begin{array}{c}\text { Numbers of } \\
\text { beneficiaries ( } \% \text { of } \\
\text { total employment) }\end{array}$ & Comments \\
\hline Austria & $\begin{array}{l}\text { Workers with a } \\
\text { work history of over } \\
\text { three years and with } \\
\text { the current } \\
\text { employer for the } \\
\text { past two years }\end{array}$ & Individual workers & $\begin{array}{l}\text { A daily allowance of } \\
\text { EUR } 14.53 \text { for a } \\
\text { period of 3-12 } \\
\text { months }\end{array}$ & $\begin{array}{l}\text { Austrian } \\
\text { Employment Service }\end{array}$ & $\begin{array}{l}2263 \text { in } 2002 \\
(0.1 \%)\end{array}$ & \\
\hline Belgium & Full-time workers & Employers & $\begin{array}{l}\text { Full wage costs (up } \\
\text { to } 80-120 \text { hours for } \\
\text { general education, } \\
120-180 \text { hours for } \\
\text { vocational training, } \\
\text { and } 180 \text { hours for } \\
\text { workers who take } \\
\text { both general and } \\
\text { vocational courses } \\
\text { during the same } \\
\text { year) and the direct } \\
\text { costs }\end{array}$ & $\begin{array}{l}\text { Social security } \\
\text { contribution }\end{array}$ & $\begin{array}{l}60270 \text { during } \\
2000 / 01 \text { academic } \\
\text { year }(1.5 \%)\end{array}$ & \\
\hline Finland & $\begin{array}{l}\text { Employees with a } \\
\text { work history of over } \\
10 \text { years }\end{array}$ & Individual workers & $\begin{array}{l}\text { EUR } 440 \text { per month } \\
\text { plus an earning- } \\
\text { related amount } \\
\text { covering } 15-20 \% \text { of } \\
\text { the last monthly } \\
\text { wage up to } 1 \text { year }\end{array}$ & $\begin{array}{l}\text { Education and } \\
\text { training insurance }\end{array}$ & $\begin{array}{l}5236 \text { in } 2002 \\
(0.2 \%)\left({ }^{2}\right)\end{array}$ & \\
\hline France & $\begin{array}{l}\text { Workers with a } \\
\text { work history of over } \\
24 \text { months and who } \\
\text { worked with the } \\
\text { current employer } \\
\text { during the last } 12 \\
\text { months }\end{array}$ & Individual workers & $\begin{array}{l}80-90 \% \text { of the } \\
\text { foregone wage up } \\
\text { to one year or } 1200 \\
\text { hours }\end{array}$ & $\begin{array}{l}\text { Employers' } \\
\text { contribution ( } 0.2 \% \\
\text { of the wage bill) to } \\
\text { the accredited } \\
\text { bipartite } \\
\text { organisations } \\
\text { (Opacif) }\end{array}$ & $\begin{array}{l}26169 \text { in } 2001 \\
(0.1 \%)\end{array}$ & \\
\hline Japan & $\begin{array}{l}\text { Employed persons } \\
\text { who are covered by } \\
\text { the employment } \\
\text { insurance }\end{array}$ & Employers & $\begin{array}{l}\text { One quarter of the } \\
\text { wage costs and one } \\
\text { quarter of the direct } \\
\text { costs (one third for } \\
\text { SMEs) }\end{array}$ & $\begin{array}{l}\text { Employment } \\
\text { insurance }\end{array}$ & $\begin{array}{l}3265 \text { in fiscal year } \\
2002(0.01 \%)\end{array}$ & $\begin{array}{l}\text { A budget of JPY } 0.7 \\
\text { billion was made } \\
\text { available for fiscal } \\
\text { year } 2002\end{array}$ \\
\hline
\end{tabular}




\begin{tabular}{|c|c|c|c|c|c|c|}
\hline Country ${ }^{(1)}$ & Eligibility & $\begin{array}{c}\text { Subsidies } \\
\text { provided to }\end{array}$ & Subsidy ranges & $\begin{array}{l}\text { Funding } \\
\text { mechanism }\end{array}$ & $\begin{array}{c}\text { Numbers of } \\
\text { beneficiaries ( } \% \text { of } \\
\text { total employment) }\end{array}$ & Comments \\
\hline Korea & n.a. & Employers & $\begin{array}{l}\text { One third of the } \\
\text { wage costs and part } \\
\text { of direct costs }\end{array}$ & $\begin{array}{l}\text { Employment } \\
\text { insurance }\end{array}$ & $\begin{array}{l}7756 \text { in } 2000 \\
(0.04 \%)\end{array}$ & $\begin{array}{l}\text { Total subsidy of } \\
\text { KRW } 5589 \text { million } \\
\text { in } 2000\end{array}$ \\
\hline Norway & $\begin{array}{l}\text { Workers with a } \\
\text { work history of over } \\
\text { three years and with } \\
\text { the current } \\
\text { employer for the } \\
\text { past two years }\end{array}$ & Individual workers & $\begin{array}{l}\text { NOK } 80000 \text { per } \\
\text { year, of which } 60 \% \\
\text { is a loan, } 25 \% \text { is an } \\
\text { unconditional grant } \\
\text { and } 15 \% \text { is } \\
\text { converted from loan } \\
\text { to grant when the } \\
\text { student succeeds in } \\
\text { the examination }\end{array}$ & $\begin{array}{l}\text { State Education } \\
\text { Loan Fund }\end{array}$ & n.a. & $\begin{array}{l}\text { Only for formal } \\
\text { education }\end{array}$ \\
\hline Spain & $\begin{array}{l}\text { Workers who have } \\
\text { been employed by } \\
\text { the same firm for at } \\
\text { least one year }\end{array}$ & Individual workers & $\begin{array}{l}\text { Full foregone wages } \\
\text { up to } 200 \text { working } \\
\text { hours }\end{array}$ & $\begin{array}{l}\text { Social partners' } \\
\text { mandatory } \\
\text { contribution to the } \\
\text { Tripartite } \\
\text { Foundation }\end{array}$ & $\begin{array}{l}1394 \text { in } 2002 \\
(0.01 \%)(3)\end{array}$ & \\
\hline Sweden & $\begin{array}{l}\text { Workers who have } \\
\text { been employed for } \\
\text { at least six } \\
\text { consecutive months } \\
\text { or with a work } \\
\text { history of over } 12 \\
\text { months during the } \\
\text { last two years }\end{array}$ & Individual workers & $\begin{array}{l}\text { Grants and loans of } \\
\text { SEK } 33880 \text { for } 20 \\
\text { weeks full-time } \\
\text { studies; a } \\
\text { supplementary loan } \\
\text { for the workers } \\
\text { aged } 25 \text { or older if } \\
\text { the income of the } \\
\text { beneficiary during } \\
\text { the } 12 \text { months } \\
\text { immediately } \\
\text { preceding the } \\
\text { studies has been } \\
\text { above a certain } \\
\text { threshold }\end{array}$ & $\begin{array}{l}\text { Study allowance by } \\
\text { the government }\end{array}$ & $0.7 \%$ in 2002 & $\begin{array}{l}\text { Only for formal } \\
\text { education }\end{array}$ \\
\hline $\begin{array}{l}\text { (1) Countries w } \\
\text { Portugal, ar } \\
\text { (2) The figure } r \\
\text { (3) The figure } r \\
\text { NB: n.a.: Inform }\end{array}$ & $\begin{array}{l}\text { ithout specific subsidy sc } \\
\text { not included in the table } \\
\text { efers to the number of em } \\
\text { efers to the number of ind } \\
\text { lation not available. }\end{array}$ & $\begin{array}{l}\text { hemes or where the rel } \\
\text { ployees who have taken } \\
\text { lividual training permits }\end{array}$ & $\begin{array}{l}\text { d schemes are governed } \\
\text { Iternation leaves, of whic } \\
\text { oproved by Forcem. }\end{array}$ & $\begin{array}{l}\text { by collective agreement } \\
\text { ch only roughly } 17 \% \text { ind }\end{array}$ & $\begin{array}{l}\text {, such as Australia, Gerr } \\
\text { icate studying was the m }\end{array}$ & $\begin{array}{l}\text { lany, the Netherlands anc } \\
\text { jor reason. }\end{array}$ \\
\hline
\end{tabular}

Source: OECD Secretariat on the basis of information supplied by the countries in question.

In most countries that have training leave schemes, however, only a very limited number of employees have participated in them. Belgium and Sweden, where almost $1 \%$ of workers have been on leave each year since the establishment of the schemes, are two exceptions to this pattern. However, training leaves tend to be more popular among women than men, since they are seen as a flexible way to reconcile further training needs with family responsibilities. For instance, in Denmark there were about 2000 men and 6000 women on training leave in the second quarter of the year 2000 (representing about $0.1 \%$ and $0.5 \%$ of employment, respectively; EIRO, 2001). In Sweden, women take up training leave twice as frequently as men. In Austria, training sabbaticals were disproportionately used by women until the scheme was reformed and going on training leave soon after maternity leave forbidden. Belgium, where only one quarter of the employees on training leave were women in the mid1990s, is an exception to this pattern, probably due to the fact that part-time workers are excluded by the Belgian scheme (Cedefop, 2001).

\subsection{Framework conditions}

The effectiveness of co-financing policies that aim to increase demand by employers and employees 
(demand in the upstream market) hinges in part on certain framework conditions - the policy and institutional environment in which they are implemented. First, barriers to entry of bona fide training providers must be relatively low to allow supply shifts accommodating demand needs without raising costs. Second, information on the nature, conditions (location, duration, timing), cost and quality of education and training opportunities must be readily available to individuals and employers in order to ensure efficient allocation of resources for investment in education and training and foster cost-sharing as well as cooperative behaviours. Third, information on the nature and level of skills and competencies that are acquired by individuals through self-financed training must be transparently signalled to external labour markets so that workers can capitalise on what they have learned when they pay for it. Many countries have introduced standardised competence-based qualification systems, according to which acquisition of qualifications is not conditioned to course attendance in vocational training or educational institutions. Under these systems, workers are allowed to take individual skill tests independently of the way skills are acquired. Yet, much remains to be done to ensure the correct functioning of these mechanisms (Bjørnåvold, 2002).

Collective agreements and trade union participation may play an important role not only in diffusing information and jointly defining curricula, but also by increasing and twisting employers' supply towards more general types of training (see Ok and Tergeist, 2003). For example, a study by the American Society for Training and Development (ASTD) of major joint labour-management training programmes suggests that these joint initiatives do result in a different mix of training activities. While only $2 \%$ of firm-supported training addresses basic literacy skills according to the ASTD's benchmarking database, this figure soars to
$15 \%$ for the joint programmes (van Buren and Erskine, 2002). The sharing of training costs between employers and individuals can also be fostered by joint training agreements to the extent that unions and work councils are in a better place to monitor training content and quality. In most European countries, participation in employer-sponsored training is significantly greater in firms with a joint training agreement than in firms without it (Chart 5). Differences in training participation rates are particularly large in Mediterranean countries (for which the participation rate in firms with negotiated agreements is more than twice as large as in other firms). Conversely, these differences are not particularly significant in the Nordic countries (except Finland) and the United Kingdom, where however training participation rates are also high in firms without joint training agreements.

Finally, other framework conditions, whose primary effect is not on training or education, have secondorder (and theoretically more ambiguous) effects on training demand and supply. For instance, institutions in the labour market affecting the distribution of wages, such as the minimum wage and employment protection legislation, modify the incentives of employers and employees to invest in training (see Acemoglu and Pischke, 1999b). Furthermore, the progressiveness of the income tax may have a bearing on individual incentives, to the extent that, on the one hand, it reduces individual appropriability of the benefits from training and, on the other hand, it reduces the opportunity cost of taking unpaid training leaves or opting for part-time work. Finally, a major obstacle for women to participate in adult learning is represented by the fact that the burden of family responsibilities is still unevenly shared within the couple (OECD, 2003a). Policies that affect the ability of households to reconcile work with family needs can have an impact on the gender-training gap. 
Chart 5: Training participation and joint training agreements -

Percentage of employees in all enterprises with/without a joint training agreement with social partners participating in employer-sponsored training, $1999\left({ }^{1}\right)$

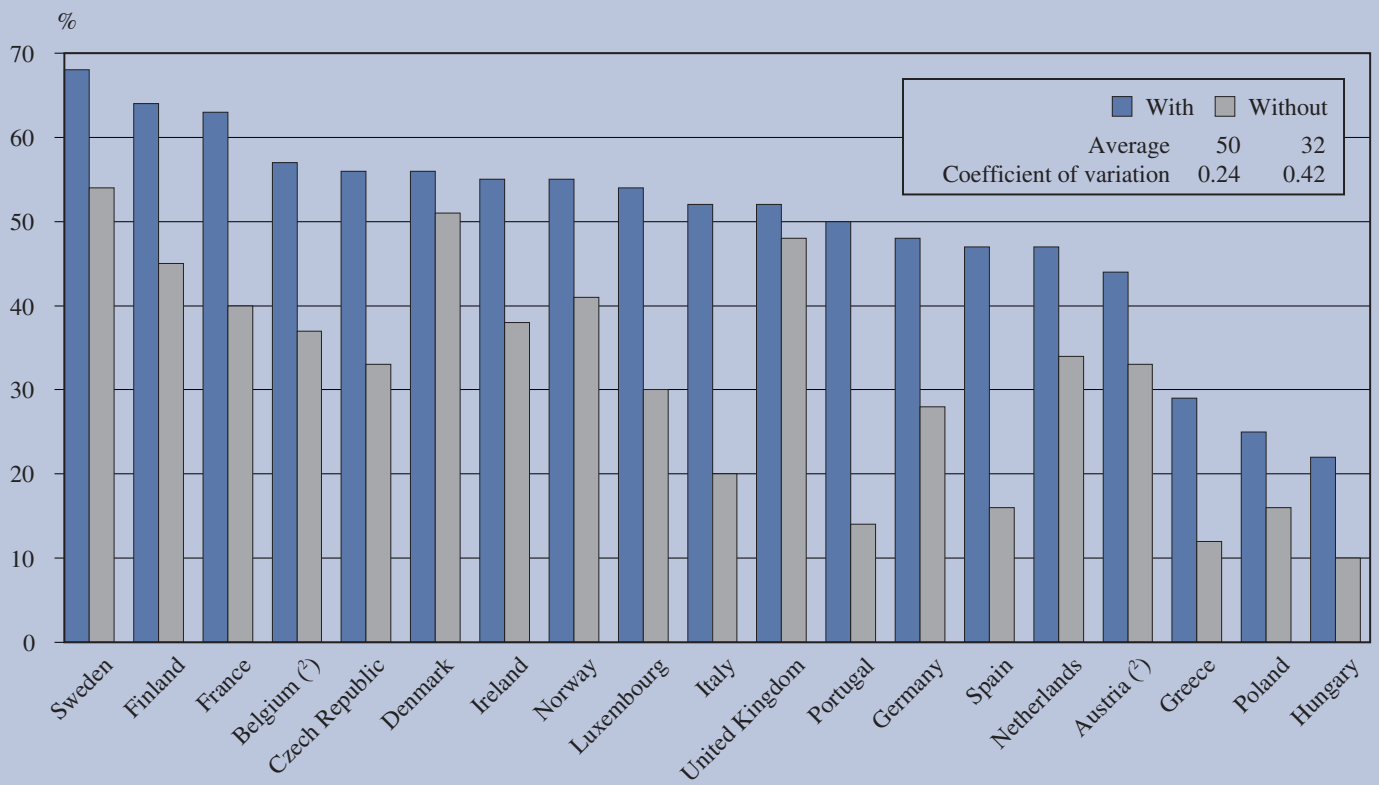

(1) Countries are ranked from left to right in descending order of the percentage of employees in all enterprises with a joint training agreement participating in employer-sponsored training.

${ }^{2}$ Estimations include a very small number of non-training enterprises due to missing values.

Source: CVTS2. 


\section{Concluding remarks}

James Heckman has argued that in evaluating a human capital investment strategy, it is crucial to consider the entire policy portfolio of interventions together (training programmes, school-based policies, school reform, and early interventions) rather than focusing on one type of policy in isolation from the others. [...] We cannot afford to postpone investing in children until they become adults, nor can we wait until they reach school age - a time when it may be too late to intervene. Learning is a dynamic process and is most effective when it begins at a young age and continues through to adulthood' (Heckman, 2000, p. 50). This caveat has an irreplaceable importance for policy guidance. Nevertheless, as noted by Blundell (2000), Heckman's remarks do not imply that later interventions have no pay-off. There are indeed several reasons why systematic provision of front-end formal education and training preceding entry to the labour market is increasingly insufficient and it might be desirable to flank early interventions with policies for adult learning. This paper has provided evidence that training has a positive impact on individual labour market performance. Despite this evidence, in the absence of policy interventions, training might be suboptimally provided because of imperfections in labour, capital and training markets. However, carefully designed co-financing mechanisms, by leveraging the resources of all actors that can benefit from training, could promise policy innovations to improve training outcomes, as appropriate. 


\section{Appendix}

The analysis of this paper is limited to individuals aged from 25 to 54 years. Due to data availability a person is defined as employed if he/she works at least 15 hours per week. Moreover, employees' gross hourly wages are computed from gross monthly earnings in the main job at the date of the interview, by dividing them by $52 / 12$ and by usual weekly hours of work. Overtime pay and hours are included.

The question on employment security in the ECHP is as follows: 'How satisfied are you with your present job in terms of job security?'. Replies are quantified on a 1-6 Likert scale from not satisfied to fully satisfied. The median reply in the sample is 4 , while the mode is 5 .

The ECHP release used in this paper contains data from 1994 to 2000. Although, in principle, the ECHP covers 15 European Union countries, the country sample in the different analyses is chosen on the basis of data availa- bility. Luxembourg and Sweden never appear in the analysis - due to the small sample size for the former and the absence of longitudinal data for the latter. SOEP and BHPS sources are preferred for Germany and the United Kingdom, respectively, since data from ECHP sources on these two countries are not available after 1996. Nevertheless, due to a change in the BHPS questionnaire, starting in 1998, only the waves 19982000 are used for the United Kingdom; and due to the lack of information on subjective perceptions of job security in the SOEP, ECHP data are used for Germany in that analysis. Furthermore, data for Austria are not available in 1994 and data for Finland are not available in 1994 and 1995. In addition, observations for certain countries and certain years are excluded from the sample due to the lack of time-series comparability of wage data - notably, 1995 for Austria, 1994 and 1997-2000 for France, 1994-96 for Greece, 2000 for Ireland, and 1994 for Spain. Finally, employment security data are not available for Ireland. 


\section{References}

Acemoglu, D. and J-S. Pischke (1998), 'Why do firms train? Theory and evidence', Quarterly Journal of Economics, Vol. 113, pp. 79-119.

Acemoglu, D. and J-S. Pischke (1999a), 'The structure of wages and investment in general training', Journal of Political Economy, Vol. 107, No 3, pp. 539-572.

Acemoglu, D. and J-S. Pischke (1999b), 'Beyond Becker: Training in imperfect labour markets', Economic Journal, Vol. 109, No 453, pp. 112-142.

Acemoglu, D. and J-S. Pischke (2003), 'Minimum wage and on-the-job training', Research in Labour Economics, Vol. 23, forthcoming.

Agell, J. and K. Lommerud (1997), 'Minimum wages and the incentives for skill formation', Journal of Public Economics, Vol. 64, pp. 25-40.

Arulampalam, W., A. Booth and M. Bryan (2004a), 'Are there asymmetries in the effects of training on the conditional male wage distribution?', IZA Discussion Paper, No 984, January.

Arulampalam, W., A. Booth and M. Bryan (2004b), 'Training and the new minimum wage', Economic Journal, Vol. 114, pp. C87-C94.

Ballot, G., F. Fakhfakh and E. Taymaz (2002), 'Who benefits from training and $\mathrm{R} \& \mathrm{D}$ ? The firm or the workers? A study on panels of French and Swedish firms', ERMES Working Paper No 01-12.

Barron, J. M., M. C. Berger and D. A. Black (1999a), 'Do workers pay for on-the-job training?', Journal of Human Resources, Vol. 34, No 2, pp. 235-252.

Barron, J. M., M. C. Berger and D. A. Black (1999b), 'Replacing general with specific training: Why restrict- ing alternatives makes sense', Research in Labour Economics, Vol. 18, pp. 281-302.

Bartel, A. (2000), 'Measuring the employer's return on investments in training: evidence from the literature', Industrial Relations, Vol. 39, pp. 502-524.

Bassanini, A. and G. Brunello (2003), 'Is training more frequent when wage compression is higher? Evidence from the European Community household panel', IZA Discussion Paper No 839, August.

Becker, G. S. (1975), Human capital, second edition, Columbia University Press, New York.

Bellmann, L. and H. Düll (2001), 'Die zeitliche Lage und Kostenaufteilung von Weiterbildungsmassnahmen. Empirische Ergebnisse auf der Grundlage des IABBetriebspanels', in R. Dobischat and H. Seifert (eds.), Lernzeiten neu organisieren, Hans Böckler Stiftung, Düsseldorf.

Betcherman, G., K. Olivas and A. Dar (2004), 'Impacts of active labour market programmes: New evidence from evaluations with particular attention to developing and transition countries', World Bank Social Protection Discussion Paper No 0402, January.

Bishop, J. H (1997), 'What we know about employerprovided training: A review of the literature', Research in Labour Economics. Vol. 16, pp. 19-87.

Bjørnåvold, J. (2002), 'Assessment of non-formal learning: A link to strategies for lifelong learning', in D. Colardyn (ed.), Lifelong learning: which ways forward?, second edition, Lemma Publishers, Utrecht.

Blundell, R. (2000), ‘Comments on James Heckman's 'Policies to foster human capital' Research in Economics, Vol. 54, No 1, pp. 57-60. 
Blundell, R., L. Dearden and C. Meghir (1999), 'Workrelated training and earnings', mimeo, Institute for Fiscal Studies, London.

Booth, A. and M. Bryan (2002), 'Who pays for general training? New evidence for British men and women', IZA Discussion Paper No 486, April.

Brunello, G. and M. De Paola (2004), 'Market failures and the under-provision of training', mimeo, July.

Brunello, G. and F. Gambarotto (2004), 'Agglomeration effects on employer-provided training: evidence from the UK', IZA Discussion Paper No 1055, March.

Burchell, B., A. Ladipo and F. Wilkinson (eds.) (2001), Job insecurity and work intensification, Routledge, London.

Callender, C. (2002), 'Loans for further education students', in Mick Fletcher, (ed.) Loans for lifelong learning, Learning and Skills Development Agency, London.

Cedefop (2001), Vocational education and training in Belgium, Thessaloniki.

Dearden, L., H. Reed and J. Van Reenen (2000), 'Who gains when workers train? Training and productivity in a panel of British industries', IFS Working Paper No 00-04.

Dobischat, R. and H. Seifert (2001), 'Betriebliche Weiterbildung und Arbeitszeitkonten', WSI-Mitteilungen, No 2, February.

EIRO (2001), 'Working time developments and the quality of work: Denmark', EIROnline, www.eiro.eurofound.ie/.

European Commission (2004), Jobs, jobs, jobs: Creating more employment in Europe, European Communities, Luxembourg.

Farber, D. (2003), 'Job loss in the United States, 19812001', NBER Working Paper No 9707, May.

Fougère, D., D. Goux and E. Maurin (2001), 'Formation Continue et Carrières Salariales: Une Évaluation sur Données Individuelles', Annales d'Économie et de Statistique, No 62, pp. 49-69.
Frazis, H. and M. Loewenstein (1999), 'Reexamining the returns to training: functional form, magnitude, and interpretation', BLS Working Paper No 325.

Gasskov, V. (1998), 'Levies, leave and collective agreements incentives for enterprises and individuals to invest in training', Vocational Training: European Journal, No 13.

Gasskov, V. (2001), 'Government interventions in private financing of training', ILO, Geneva, mimeo.

Gerfin, M. (2003), 'Firm-sponsored work-related training in frictional labour markets: An empirical analysis for Switzerland', Universität Bern Diskussionschriften, No 03-17, October.

Gibbons, R. and M. Waldman (1999), 'Careers in organisations: Theory and evidence', in Ashenfelter, Orley and Card, David (eds.) Handbook of Labour Economics. Vol. 3B, North-Holland, Amsterdam.

Green, F. (2003), 'The rise and decline of job insecurity', UKC Discussion Papers in Economics, No 03/05.

Green, F., B. Burchell and A. Felstead (2000), 'Job insecurity and the difficulty of regaining employment: an empirical study of unemployment expectations', Oxford Bulletin of Economics and Statistics, Vol. 62, pp. 855-884.

Håkanson, C., S. Johanson and E. Mellander (2002), 'Firm training viewed from stabilisation and growth policy perspectives', IFAU, Stockholm, mimeo.

Heckman, J. J. (2000), 'Policies to foster human capital', Research in Economics, Vol. 54, No 1, pp. 3-56.

Heckman, J. J., R. J. Lalonde and J. A. Smith (1999), 'The economics and econometrics of active labour market programmes', in Ashenfelter, O. and Card, D. (eds.), Handbook of Labour Economics, Vol. 3A, pp. 18652097, North-Holland, Amsterdam.

Heywood, J. S., W. S. Siebert and X. Wei (2002), 'Worker sorting and job satisfaction: The case of union and government jobs', Industrial and Labour Relations Review, Vol. 55, pp. 595-609.

Hill, E. T. (2001), 'Post-school-age training among women: Training methods and labour market outcomes 
at older ages', Economics of Education Review, Vol. 20, pp. 181-191.

Hui, S.-W. and J. A. Smith (2002), 'The labour market impacts of adult education and training in Canada', mimeo, University of Western Ontario and University of Maryland.

Kuckulenz, A. and T. Zwick (2003), 'The impact of training on earnings: differences between participant groups and training forms', ZEW Discussion Paper No 03-57.

Kurosawa, M. (2001), 'The extent and impact of enterprise training', Japanese Economic Review, Vol. 52, No 2, pp. 224-242.

Lalonde, R. (1986), 'Evaluating the econometric evaluations of training programmes with experimental data', American Economic Review, Vol. 76, No 3, pp. 604-620.

Layard, R. (2003), ‘A note for discussion', meeting of the Employment, Labour and Social Affairs Committee at the Ministerial Level, Forum: Good jobs/bad jobs: Myth and realities, DELSA/ELSA/MIN(2003)5, OECD, Paris.

Leuven, E. (2003), 'The economics of training: a survey of the literature', mimeo, University of Amsterdam.

Leuven, E. and H. Oosterbeek (2004), 'Evaluating the effect of tax deductions on training', Journal of Labour Economics, forthcoming.

Leuven, E., H. Oosterbeek., R. Sloof and C. Van Klaveren (2004), 'Worker reciprocity and employer investment in training', Economica, forthcoming.

Loewenstein, M. A. and J. R. Spletzer (1998), 'Dividing the costs and returns to general training', Journal of Labour Economics, Vol. 16, No 1, pp. 142-171.

Loewenstein, M. A. and J. R. Spletzer (1999), 'General and specific training: evidence and implications', Journal of Human Resources, Vol. 34, No 4, pp. 710-733.

Malcomson, J. M. (1999), 'Individual employment contracts', in Ashenfelter, O. and Card, D., (eds.) Handbook of Labour Economics. Vol. 3B, North-Holland, Amsterdam.
Malcomson, J. M. (1997), 'Contracts, hold-up, and labour markets', Journal of Economic Literature, Vol. 35, No 4, pp. 1916-1957.

Malcomson, J. M., J. Maw and B. McCormick (2003), 'General training by firms, apprentice contracts, and public policy', European Economic Review, Vol. 47, No 1, pp. 197-227.

Martin, J. P. and Grubb, D. (2001), 'What works and for whom: A review of OECD countries' experiences with active labour market policies', Swedish Economic Policy Review, Vol. 8, No 2, pp. 9-56.

Moen, E. and A. Rosen (2002), 'Does poaching distort training?', CEPR Discussion Paper No 3468, July.

Neumark, D. and W. Wascher (2001), 'Minimum wages and training revisited', Journal of Labour Economics, Vol. 19, No 3, pp. 563-595.

Nickell, S., P. Jones and G. Quintini (2002), 'A picture of job insecurity facing British men', Economic Journal, Vol. 112, pp. 1-27.

OECD (1994), The OECD jobs study - Evidence and explanations. Part II: The adjustment potential of the labour market, Paris.

OECD (1997), Employment outlook, Paris.

OECD (1999), Implementing the OECD jobs strategy Assessing performance and policy, Paris.

OECD (2002), Employment outlook, Paris.

OECD (2003a), Employment outlook, Paris.

OECD (2003b), Education policy analysis, Paris.

OECD (2003c), Descriptions and evaluations of recent experience with mechanisms for co-financing lifelong learning: Reports prepared by national authorities and members of the ELAP network, prepared for the 'Second international seminar: Mechanisms for the cofinance of lifelong learning', London, 27-29 November, OECD, Paris.

OECD (2004), Employment outlook, Paris, forthcoming. 
Ok, W. and P. Tergeist (2003), 'Improving workers' skills: Analytical evidence and the role of the social partners', OECD Social, Employment and Migration Working Papers No 10, July.

Owens, J. (2001), 'Evaluation of individual learning accounts - Early views of customers and providers: England', DfEE Research Brief, No 294, 28 September.

Parent, D. (1999), 'Wages and mobility: The impact of employer-provided training', Journal of Labour Economics, Vol. 17, No 2, pp. 298-317.

Schmidt, S. R. (1999), 'Long-run trends in workers' beliefs about their own job security: Evidence from the general social survey', Journal of Labour Economics, Vol. 17, pp. S127-S141.

Schøne, P. (2002), 'Why is the return to training so high?', mimeo, Institute for Social Research, Oslo, December.

Smith, J. A. and P. Todd (2004), 'Does matching overcome Lalonde's critique of non-experimental estimators?', Journal of Econometrics, forthcoming.

Stevens, M. (1994), 'A theoretical model of on-the-job training with imperfect competition', Oxford Economic Papers, Vol. 46, No 4, pp. 537-562.
Stevens, M. (1999), 'Human capital theory and UK vocational training policy', Oxford Review of Economic Policy, Vol. 15, No 1, pp. 16-32.

Stevens, M. (2001), 'Should firms be required to pay for vocational training?', Economic Journal, Vol. 111, No 473, pp. 485-505.

Van Buren, M. and W. Erskine (2002), 'What works in workforce development: an ASTD/AJLMEP study of joint labour-management educational programmes', September.

Wanner, E. and D. Neumark (1999), 'Preface', Journal of Labour Economics, Vol. 17, No 4, Part 2, pp. Siii-Siv.

Waterreus, J. M. (2002), O\&O-fondsen op herhaling; Stand van zaken scholingsfondsen 2002, Max Goote, Amsterdam.

Winkelmann, L. and R. Winkelmann (1998), 'Why are the unemployed so unhappy? Evidence from panel data', Economica, Vol. 65, pp. 1-15.

York Consulting (2002), 'Evaluation of individual learning accounts: Final report', Scottish Executive, Edinburgh. 